\title{
THE ILLUMINATED BRABANTSCHE YEESTEN MANUSCRIPTS IV 684 AND IV 685 IN THE ROYAL LIBRARY OF BELGIUM: AN UNFINISHED PROJECT OF BRABANTINE HISTORIOGRAPHY
}

\author{
DESCRIPTION, LIST OF ILLUSTRATIONS AND INDEX OF \\ PERSONS DEPICTED
}

\author{
Bram Caers \& Mark Visscher
}

\begin{abstract}
The Royal Library of Belgium in Brussels is the custodian of two intriguing fifteenthcentury manuscripts that contain part of the fourteenth-century Brabantine chronicle Brabantsche yeesten, by the Antwerp council clerk Jan van Boendale (IV 684 and IV 685). One of them contains no less than 69 illuminations, while the other was obviously intended to be illustrated in the same way, but never was. They are the only medieval manuscript version of the chronicle to ever have been illustrated, making them popular among medievalistst studying the Duchy of Brabant. Surprisingly, very little scholarly work has been done on the illuminations as such, and the manuscript context in which they are found. We also see that a handful of illustrations return time and again in scholarly publications, while others are less known. Now that the Library has digitised the manuscripts and made them available online, we provide an updated description and an annotated list of illustrations, with an index of persons and places depicted. We hope to provide scholars easier access to this rich collection of illustrations, which is of interest not only to medievalistst studying Brabant, but to medievalists studying western Europe generally.
\end{abstract}

In the first half of the fourteenth century, the Antwerp council clerk Jan van Boendale wrote an extensive vernacular verse chronicle of the duchy of Brabant that would form the backbone of vernacular historiography in the Duchy for centuries to come. ${ }^{1}$ It was continued in verse in the fifteenth century, adding two extensive 'books' to Boendale's original five, and would reach new audiences in a printed prose version (Antwerp: Roland van den Dorpe, 1498) enjoying no less than three more reworked editions in the sixteenth century

(1) For a general introduction to Jan van Boendale and his literary work, see F. van Oostrom, Wereld in woorden: geschiedenis van de Nederlandse literatuur 1300-1400 (Amsterdam: Bert Bakker, 2013), 142-75. Pages 146-51 deal specifically with the chronicle, and the colour illustrations between pp. 168-69 present a two-page reprint of one of the illuminations (Brussels, Royal Library of Belgium, IV 684, 60v-61r) discussed in this contribution. 
$(1512,1518,1530) .^{2}$ Boendale's original Brabantsche yeesten has been preserved in several medieval manuscript witnesses, only four of which present a redaction of the full text with its fifteenth-century continuation - the Voortzetting - totalling seven 'books'. Other manuscripts have been preserved only in fragmentary form, or contain only part of the chronicle. ${ }^{3}$ It is remarkable that only two (fragmentary) manuscript witnesses date to the fourteenth century, with the bulk of the preserved material clustering around the middle of the fifteenth, shortly after the continuation was completed. ${ }^{4}$

While for some time now, attention in scholarship has been turning from the study of texts to the material context of the manuscripts in which these texts have been preserved, not all manuscripts of the Brabantsche yeesten have received equal scholarly attention. ${ }^{5}$ The most recent study devoting specific attention to the manuscript context of the chronicle is that of Astrid Houthuys, who looked specifically at a draft manuscript of the Voortzetting, produced in the context of the Brussels city administration. ${ }^{6}$ While Houthuys concentrated on the fifteenth-century continuation, the initial fourteenth-century text genesis has been looked at by Robert Stein and Dirk Schoenaers, both heavily relying on manuscript vari-

(2) On the verse continuation, see R. Stein, Politiek en historiografie: het ontstaansmilieu van Brabantse kronieken in de eerste helft van de vijftiende eeuw, Miscellanea Neerlandica 10 (Leuven: Peeters, 1994), and compare A. Houthuys, Middeleeuws kladwerk: de autograaf van de Brabantsche yeesten, boek VI (vijftiende eeuw) Schrift en schriftdragers in de Nederlanden in de Middeleeuwen 4 (Hilversum: Verloren, 2009). Houthuys attributed the continuation to a Wein van Cotthem. On the printed nachleben of the Brabantsche yeesten, see mainly J. Tigelaar, Brabants historie ontvouwd: die alder excellenste cronyke van Brabant en het Brabantse geschiedbeeld anno 1500 (Hilversum: Verloren, 2006). The new editions were printed by Jan van Doesborch, who took over the printing shop of Van den Dorpe's widow, see Tigelaar, Brabants historie ontvouwd, 18. The chronicle, including the continuation, was published by J.F. Willems \& J. Bormans, Les gestes des ducs de Brabant: De Brabantsche Yeesten, of rymkronyk van Braband par Jean de Klerk, d'Anvers = door Jan de Klerk, van Antwerpen. 3 vols (Brussels: Hayez, 1839-1869). The text is available online in the Digitale Bibliotheek voor de Nederlandse Letteren: https://www.dbnl.org/tekst/boen001brab01_01/ [04/07/2018].

(3) The full copies are mss. Kluit (Leiden, Universiteitsbibliotheek, Ltk 1019 [c. 1430]), Brussels/Van den Damme (Brussels, KBR 19607, 1444), Affligem (Brussels, KBR IV 684-85 [c. 1442-1444]), Tongerlo (Antwerp, Erfgoedbibliotheek Hendrik Conscience, B 15828 [second half fifteenth century]), and Vlamincx (Brussels, KBR 17012-13 [c. 1470]). Compare Deschamps 1972 and the digital repertories of the Narrative Sources of the Medieval Low Countries (www.narrative-sources.be [02/07/2018]) and the Bibliotheca Neerlandica Manuscripta et Impressa (https://bnm-i.huygens.knaw.nl/ [02/07/2018]).

(4) This period coincides with the vibrant historiographical climate in the Duchy in this period, see B. Caers, Vertekend verleden: geschiedenis (her)schrijven in vroegmodern Mechelen (1500-1650) (Hilversum: Verloren, 2019) in press, and compare Tigelaar, Brabants historie ontvouwd, 150-66; and Stein, Politiek en historiografie, 10-1 and passim.

(5) We refer to the 'New' or 'Material' Philology, propagated by Nichols in 1990 following developments in research across national philologies. See S. Nichols, "Introduction: philology in a manuscript culture," Speculum 65 (1990) 1: 1-10. For a critical discussion from the point of view of chronicle manuscripts, see B. Caers, "Layered text formation in urban chronicles: the case of an early modern manuscript from Mechelen", in Between stability and transformation: textual traditions in the Medieval Netherlands, ed. J. Oosterman \& R. Gabriël, special issue of Queeste 23-2 (2016): 154-70; and L. Demets \& J. Dumolyn, "Urban chronicle writing in late medieval Flanders: the case of Bruges during the Flemish revolt of 1482-1490," Urban history 43 (2016) 1: 28-45.

(6) Houthuys, Middeleeuws kladwerk, 22-33; comp. Stein, Politiek en historiografie, 153-65. 
ety. ${ }^{7}$ Another point of focus has been the lavish copy of the chronicle by Henricus van den Damme, produced for the city of Brussels, which sparked attention because of its colophon providing explicit information on the production of the book. ${ }^{8}$ While Van den Damme's copy certainly is a majestic manuscript and probably was intended to be illustrated further at some point, the spaces for illustrations have been left blank. That is not uncommon for Middle Dutch historiographic manuscripts of this period, and certainly for the Brabantsche yeesten. There is in fact only one manuscript in the Brabantsche yeesten complex that does contain contemporary illustrations, a rather less thoroughly studied codex preserved in the Royal Library of Belgium under signature IV 684. Together with IV 685, which was made by the same scribe but left unillustrated, it forms the so-called 'Affligem version' of the Brabantsche yeesten, even if both manuscripts just present books IV and V (out of VII) of the chronicle respectively. There has been attention for the fact that this version contains the only mention mention of 'Jan van Antwerpen' as the original author of the Brabantsche yeesten. ${ }^{9}$ Their textual content as well, has received ample attention, as it contains an interesting variant in book IV of the Brabantsche yeesten (see below). ${ }^{10}$ The illustrations, however, while present on nearly each page of one of the two manuscripts, have surprisingly not attracted much attention, apart from being used to illustrate episodes of Brabantine history. Now that the Royal Library has digitised and made available online both the illuminated manuscript IV $684^{11}$ and the unfinished sequel IV 685, we present a refined description of the manuscripts, with an overview of their contents and an annotated list of the completed illuminations in IV 684, for the benefit of scholars looking for iconography of the medieval history of Brabant and its surrounding territories.

(7) R. Stein, "Wanneer schreef Jan van Boendale zijn "Brabantse Yeesten?," Tijdschrift voor Nederlandse taal-en letterkunde 106 (1990) 4, 262-80; D. Schoenaers, "My es leet dat ics vergat': de Vijfde Partie van Lodewijk van Velthem en het vierde boek van Jan van Boendales 'Brabantsche yeesten', in De boeken van Velthem: auteur, oeuvre en overlevering, ed. B. Besamusca, R. Sleiderink \& G. Warnar, Middeleeuwse studies en bronnen 119 (Hilversum: Verloren, 2009), 231-50. Stein mainly argues that Boendale worked on his chronicle in stages, while Schoenaers explored the integration of material from Lodewijk van Velthem's continuation to Jacob van Maerlant's Spiegel historiael.

(8) See for example Stein, Politiek en historiografie, 307; comp. R. Stein, "Boekproduktie in de middeleeuwen: de betaling van de kopiist en de verluchter van een handschrift van de Brabantsche Yeesten," Spiegel historiael 24 (1989) 12, 507-12 and 547.

(9) Van den derden Eduwaert: coninc van Ingelant hoe hij van over die zee is comen in meyningen Vrancrijc te winnen ende hoe hij Doernic belach; uitgegeven met een inleiding over de Brabantse historiografie tussen ca. 1270 en ca. 1350. , ed. J. Heymans, Tekst en tijd 10 (Nijmegen: ALFA, 1983), 36. Despite this mention, Heymans seriously doubted the authorship of Boendale concerning the Brabantsche Yeesten. Today, the attribution to Boendale is more or less the communis opinio, and has held its ground in a computational analysis; see M. Kestemont, "Een stylometrisch onderzoek naar Jan van Boendales auteurschap voor de 'Brabantsche yeesten', Belgisch tijdschrift voor filologie en geschiedenis = Revue belge de philologie et d'histoire 89 (2011) 3-4, 1019-48.

(10) Schoenaers, "'My es leet'," 240-6.

(11) They can be traced in the general catalogue by their title Brabantsche yeesten, or by their author Jan van Boendale. 


\section{MATERIAL DESCRIPTION}

Manuscripts IV 684 and IV 685 present books IV and V respectively of Jan van Boendale's Middle Dutch verse chronicle Brabantsche Yeesten, dealing with the history of the duchy of Brabant during the latter part of the thirteenth and first half of the fourteenth centuries. ${ }^{12}$ The manuscripts were acquired by the General Archives from P.J. Ghysels, a land surveyor in Alost, in 1835, as becomes evident from a note in the back of IV 685. Ghysels allegedly bought them from his tobacco dealer, who intended to use them as cigar wrappings. ${ }^{13}$ They entered the Royal Library's collection in 1970 through an exchange with the General Archives, and were subsequently described by Claudine Lemaire-De Vaere in an elaborate and detailed contribution to Vijf jaar aanwinsten: 1969-1973. Her material description reads as follows:

Jan van Boendale. Brabantsche Yeesten (boek v en vi [sic], schrift, papier en rubricering volkomen gelijk); Zuidelijke Nederlanden, 15de eeuw; papier, 63 2d., gerestaureerde bladen + 63 bladen + één 16de-eeuws blad, $30,5 \mathrm{~cm} \times 23,5 \mathrm{~cm}$ en 29,5 cm $\times 21,5 \mathrm{~cm}$; wisselend aantal regels, littera bastarda; 19 de-eeuwse leren band. ${ }^{14}$

Lemaire-De Vaere adds to this an extensive description of the manuscripts' history and their contents, to which we present here some updates and new insights. ${ }^{15}$ To begin with, Lemaire dated the manuscripts tentatively to the fifteenth century in her material description, arriving at a more precise frame of 1440-1550, based on the clothing styles in the illuminations. ${ }^{16}$ While she noted the occurrence of an identical and easily discernible watermark in both manuscripts - "een T met een klokje/un T à clochette" - she was unable to trace it in any of the printed repertories. We believe it can be identified as a Greek letter Tau or a Saint Anthony's cross with a noose beneath, and resembles very closely a series of three watermarks occurring in paper used in the Louvain city administration between 1442 and $1444 .{ }^{17}$ This would confirm Lemaire-De Vaere's hypothesis as to the time in which the

(12) The content of the later versions of the Brabantsche yeesten is complex. Jan van Boendale worked on his chronicle in several stages, adding more material to book IV later in the fourteenth century. On this question, see Stein, "Wanneer schreef Boendale"; and on the place of manuscripts Brussels, Royal Library of Belgium IV 684-85 in this discussion, Schoenaers, "My es leet", 240-6.

(13) C. Lemaire-De Vaere, "Jan van Boendale, Brabantsche yeesten" in Vijf jaar aanwinsten 1969-1973: tentoonstelling georganiseerd in de Koninklijke Bibliotheek Albert I van 18 januari tot 1 maart 1975, ed. M. Wittek et al. (Brussel: Koninklijke Bibliotheek Albert I, 1975), 55-60, here: 55. The implication may be that there were more manuscripts similar to these, containing the rest of the Brabantsche yeesten, but this must remain hypothetical.

(14) Lemaire-De Vaere, "Jan van Boendale," 55. See in French: C. Lemaire-De Vaere, "Jan van Boendale, Brabantsche yeesten” in Cinq années d'acquisitions 1969-1973..., ed. M. Wittek et al. (Bruxelles: Bibliothèque Royale Albert Ier, 1975), 53-58, here 53. In French, there is no mistake in the book numbers. In the following, we refer to the Dutch edition.

(15) Lemaire-De Vaere, "Jan van Boendale," 55-60.

(16) Lemaire-De Vaere, "Jan van Boendale," 59.

(17) We were able to circumvent the printed repertories thanks to Piccard online, a central watermark database hosted by the Hauptstaatsarchiv Stuttgart. See: http://www.piccard-online.de [05/07/2018] s.v. 'An- 
manuscripts were produced, and may indeed add impetus to her assertion that the manuscripts were not initially produced in or for a monastic context. ${ }^{18}$ We believe that considering the subject matter of the manuscripts in question and the history and provenance of other Brabantsche yeesten manuscripts, it is safe to say that IV 684 and IV 685 were produced in the Duchy of Brabant, narrowing down Lemaire-De Vaere's prudent localisation in the "Southern Low Countries". Taking into account the fact that the watermark has only been attested in paper used in the Louvain city administration, we may even posit the hypothesis that the manuscripts and the historiographical project to which they testify, can be situated in the circles of the city administration of the city of Louvain. This would not be surprising as precisely in this period, the cities were actively taking up their role in the historiography of the duchy, as is evident from the continuation of the Brabantsche yeesten which is closely tied to Brussels. ${ }^{19}$ A Louvain version of the Brabantine chronicle would side with evolutions towards a local recuperation of regional history that culminated in the later fifteenth century in local and urban histories, often based on regional chronicles such as the Brabantsche yeesten, as was the case in Mechelen and in 's-Hertogenbosch around the turn of the century. ${ }^{20}$ An origin in Louvain therefore is tempting, but needs to remain hypothetical.

Both codices are presently in a modern binding, consist of 63 leaves and currently measure about $305 \times 235 \mathrm{~mm}$ and $295 \times 215 \mathrm{~mm}$ respectively. The intensive restoration of both manuscripts and their rebinding make it hard to discern the original quire structure. There are a few catchwords (custodes) in the scribe's handwriting which enable us to partly reconstruct the manuscripts' arrangement (IV 684: fols 24v [p. 41], 36v [p. 65]; IV 685 pp. 37, 59 [61], $83[85]^{21}$ and 105 [109]). The occurrence of the catchwords points in the direction of quires of twelve pages, or three bifolia. ${ }^{22}$ Both manuscripts contain two sets of page numbers, one of which we believe dates to the (late) sixteenth century. ${ }^{23}$ The other, and a consistent foliation only present in IV 684, have been executed in pencil and date to more modern

toniuskreuz', or numbers 125306, 125308, 125309. Number 125307 is very similar as well, and was traced in a letter in the city archives in Cologne. In terms of size, it is very close to numbers 125308-9.

(18) Lemaire-De Vaere, "Jan van Boendale," 60.

(19) Stein, Politiek en historiografie, 153-66.

(20) See for 's-Hertogenbosch: Kroniek van Peter van Os: geschiedenis van 's-Hertogenbosch en Brabant van Adam tot 1523, ed. A.M. van Lith-Droogleever Fortuijn et al., Rijks geschiedkundige publicatiën, Kleine serie 87 (Den Haag: Instituut voor Nederlandse Geschiedenis, 1997); and for Mechelen: Caers, Vertekend verleden.

(21) This in fact was an instruction that failed to lead to a correct binding. The mistake has been repaired in the current, modern rebinding, but was still present when an earlier hand noticed: "siet het vervolg van dit cap. op het 114 blat".

(22) When we include the seven pages before the page numbering starts (and assume they are no separate gathering), it becomes clear that in IV 684 one folio is missing after the last catchword. In IV 685, before the third quire, a gathering of two bifolia has been made. Other arrangements cannot be excluded, naturally.

(23) During restoration, IV 684 suffered the loss of the greater part of its margins. In some instances, the sixteenth-century page numbers are still visible, e.g. fols $7 \mathrm{v}, 8 \mathrm{v}, 13 \mathrm{v}, 18 \mathrm{v}, 28 \mathrm{v}, 34 \mathrm{v}, 56 \mathrm{r}, 56 \mathrm{v}, 58 \mathrm{r}, 60 \mathrm{v}, 60 \mathrm{v}-61 \mathrm{r}$, 64r. For IV 685, we refer to the sixteenth-century page numbers with the corrected modern numbers between square brackets. For IV 684, we refer to the consistent folio numbers, as the sixteenth-century page numbers have been cut off in most cases and the modern replacements are not consistent. 


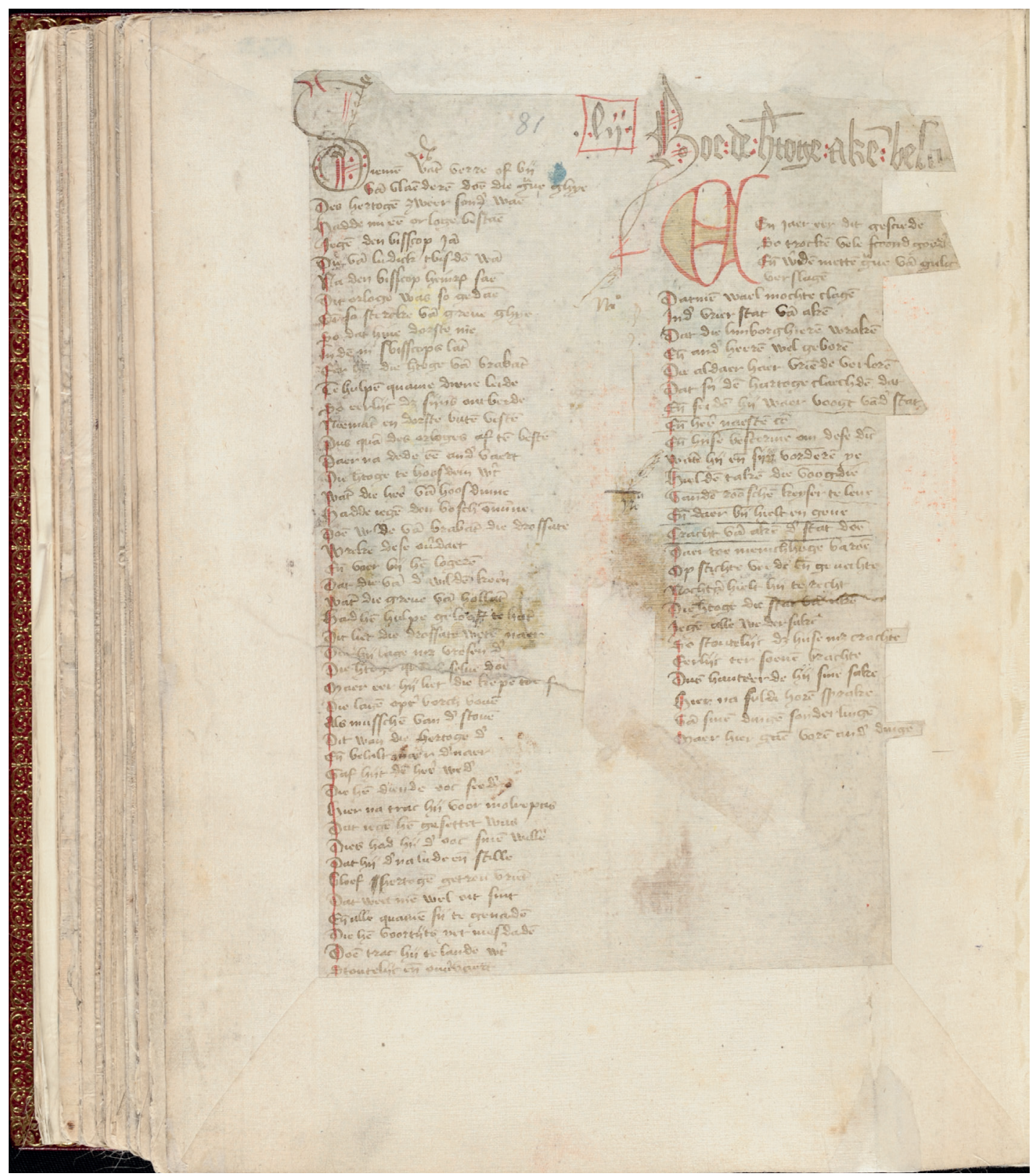

Fig. 1: Restoration with cut-outs; IV 684, fol. 44v.

times. ${ }^{24}$ Especially IV 684 has suffered considerable damage over time, showing stains most often in the upper left corner (recto) close to the binding (especially fols 1-19).

(24) These modern page numbers present a number of intriguing mistakes, especially in the table of contents of both manuscripts. Their high page numbers in ms. IV 684 (109 to 114) seem to suggest that the table used to be in the back of the manuscript, but the book contains more than 108 pages. The table of contents of ms IV 685 on the other hand, seems to mix a system of page and folio numbers. 


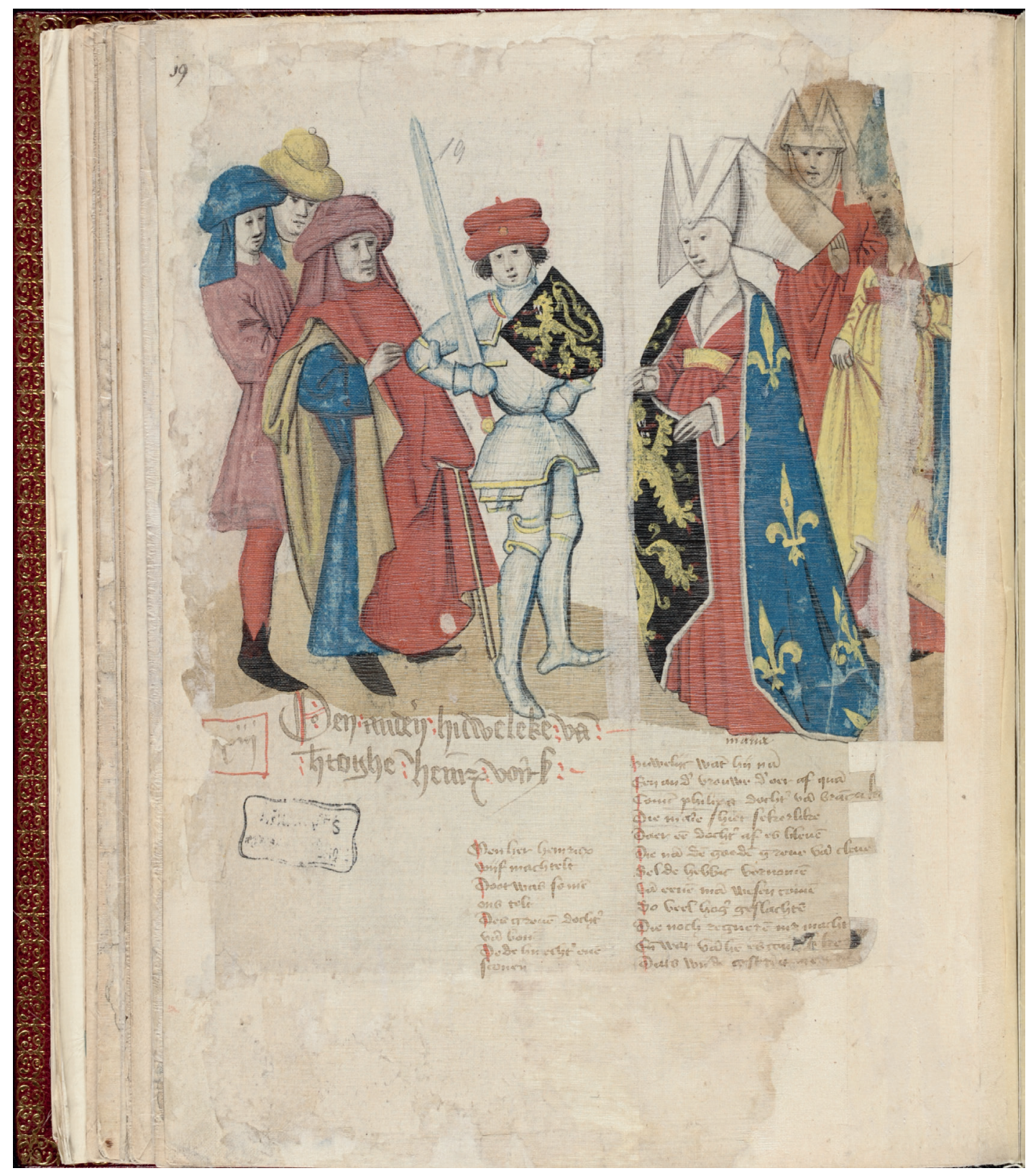

Fig. 2: A late sixteenth-century page number on restored paper; IV 684, fol. 13v.

It has been heavily restored, most of the pages having been framed in new sheets of paper, at times leaving windows for isolated text such as catchwords (e.g. 62v) or marginal dates (e.g. 25v) or showing intricate cut-outs for verse lines outside of the frame (e.g. 44v, 61v).

While the present state is fairly recent, we believe that the restoration was executed in at least two different steps, with the first initiatives predating the acquisition by the General Archives in 1835 . On $13 \mathrm{v}$ and $7 \mathrm{v}$, an older page number appears outside the boundaries of the original 
paper, and on fols $58 \mathrm{r}$ and 64r, page numbers in the same hand were pasted over with the more recent paper frame. Folio 44r, then, shows how a stamp of the General Archives partly covers a restoration stage between the original paper and the nineteenth-century reframing.

It would seem that when the older page numbers were inserted, the first attempts at restoration had been made. In the same period, previous staining was written over in a late sixteenth-century hand (e.g. IV 684: 9r, 10r, 14r, 15r, 16r). In IV 685, a similar process in separate stages could have been at work, with a later hand (or a falsification?) adding text on pp. 34-35, as well as an additional leaf in the back. ${ }^{25}$ It is very well possible that this hand is the same that added the page numbers. A hand that probably predates this one added names and short notes, often in Latin, relating to heraldry (e.g. IV 684: 29v) or the persons depicted in some of the illustrations (e.g. 21r, 23r, 25r, 30r) ${ }^{26}$ It is known that the manuscript entered the library of the monastery of Affligem in the sixteenth century, which makes it likely that these notes (and possibly the first initiatives in restoration?) were made by monks in this context.

In their original mid-fifteenth-century setup however, the manuscripts were written by a single scribe in a fast, but consistent littera hybrida in two columns, leaving large spaces for decorations in both volumes. The textual lay-out demonstrates that it was the intention to produce amply illustrated manuscripts from the onset. Vertical rulings produced room for two columns, but these where not often used in their entirety. Even pages without illumination often have just one fully used column containing up to 45 verse lines (with verse lines varying in number on each page), the second column mostly containing only up to ten lines of text. Initials and capitals on the upper line in most cases have been executed elaborately and adorned with red pen decoration expanding vertically into the upper margins. The verse lines show consistent rubrication throughout both manuscripts, performed in a rather hasty and at times somewhat sloppy way.

In terms of content, the manuscripts IV 684 and IV 685 present a peculiar version of the Brabantsche yeesten. They are said to contain books IV and V of the chronicle generally speaking, but they differ from other manuscripts containing the same material. ${ }^{27}$ Manuscript IV 684 presents a version of book IV of Boendale's chronicle heavily supplemented with material from Lodewijk van Velthem's fourteenth-century continuation to Jacob van Maerlant's Spiegel historiael, a thirteenth-century world chronicle. Maerlant's text had served Boendale as a main source for books I-III, but as it breaks off in the beginning of the twelfth century, the Antwerp chronicler had relied on other sources to continue his work in

(25) The note contains supposedly additional text collated from other Brabantsche yeesten manuscripts, but probably refers to the manuscripts IV 684-85 themselves; see Lemaire-De Vaere, "Jan van Boendale, Brabantsche yeesten," 55.

(26) There is post-restoration staining as well, e.g. in the final pages of IV 685.

(27) Dirk Schoenaers has looked at how exactly three manuscript sources of the Brabantsche yeesten incorporate material from the Vijfde Partie, and has shown that the version in IV 684 contains many variants when compared to other known versions - manuscripts Tongerlo (Antwerp, EHC, B 15828) and Van den Damme (Brussels, Royal Library, 19607); see Schoenaers, “'My es leet'," 240-6. 
books IV and V. Jacob van Maerlant's chronicle was continued, however, by Lodewijk van Velthem, a Brabantine parish priest working in about the same time as Jan van Boendale. Material from his continuation to the Spiegel historiael can be found in three manuscript versions of book IV of the Brabantsche yeesten, one of which is being the Affligem version discussed here. The insertion of this material, however, differs in all three, which has led Schoenaers to interesting assumptions about the text genesis of (these) versions of book IV. ${ }^{28}$ The evidence so far is inconclusive, but it is fair to hypothesise that Boendale himself worked on his own book IV, incorporating material from Velthem. ${ }^{29}$ Manuscript IV 684 in any case, presents a version in which material from the Brabantsche yeesten and from the Spiegel historiael is not merely presented next to each other. An effort was made to integrate both versions of the same stretch of history into one narrative. This effort was not always successful: the succession crisis after Duke Henry IV of Brabant, for instance, is narrated (and depicted) twice (illuminations: 34r (see image 3) and 40r). ${ }^{30}$ In an attempt to look for a pattern in the alterations, Schoenaers noted that by leaving out unnecessary passages and stressing others, the intention may have been to make Duke John I of Brabant stand out as a valiant (but individual) warrior.

While the situation in book IV has received more scholarly attention than that in book $\mathrm{V}$, here as well, the Affligem version provides an intriguing variant to other Brabantsche yeesten manuscripts. IV 685, containing book V of the chronicle, is the sole manuscript not breaking off after the year 1347. It continues well into the year 1351, narrating (among other events) the bubonic plague in Brussels and the Battle of Zwartewaal, which marked the start of the Hook and Cod Wars in Holland. Both IV 684 and IV 685 also contain much more chapter headings than any other known version, as these also seem to serve as captions to the illustrations. ${ }^{31}$

\section{INITIALS AND ILLUMINATIONS}

In both manuscripts, there are two types of initials. One is an initial apparently written by the scribe, flourished with pen-work in red and black. These occur only in the top of the page or in the chapter headings. Another is a lombard-like initial that is generally several lines in height, and that has been executed in red pen-work and yellow ink (for reference, see image 1, where both initials occur together). This type is found more in IV 685 than in IV 684, suggesting that the latter manuscript, despite its complete programme of illustrations, is unfinished as well. The presence of blank spaces and the absence of the first letter of the beginning verse at least suggest that it was the intention to include initials. In IV

(28) Schoenaers, “"My es leet'," 250.

(29) Compare Stein, "Wanneer schreef Boendale"; and Schoenaers, "My es leet'," 231-6 and 250.

(30) Schoenaers, “"My es leet'," 240.

(31) The edition by Willems contains 17 and 60 chapters, respectively, see Willems \& Bormans, Les gestes des ducs de Brabant. 
684, they have been executed only in a handful of cases (fols $4 \mathrm{v}, 14 \mathrm{v}$ [an elaborate fish], $33 \mathrm{v}, 44 \mathrm{v}, 53 \mathrm{r}, 55 \mathrm{r}$ [two], 55v, 57r, 57v) while just one blank space has a waiting letter (36v). While unillustrated, IV 685 contains far more coloured initials (pp. 7, 15, 31, 36 [two], 37, 38, 39, 49 [51], 53 [55], 54 [56], 63 [65 - shaded in red], 64 [66], 73 [75], 74 [76], 76 [78 - two], 77 [79], 78 [80], 80 [82], 82 [84], 83 [85], 90 [94], 97 [101], 101 [105], 102 [106], 103 [107], 106 [110], 112 [116]). The disproportionality in the initials might give the impression that the makers of the manuscripts wanted to compensate for the lack of illustrations in IV 685 by inserting more initials, but many blank spaces remain in this manuscript as well, so that it is difficult to provide a conclusive explanation.

Nearly every page of manuscript IV 684 has been illustrated with water-colour drawings with most images covering well over half a page and one covering verso and recto of two pages, leaving room only for a chapter title. Manuscript IV 685 has blank spaces intended for a similar scheme of illuminations. Countering Willems' assumption that the illustrations must have been added some time after the text, Lemaire-De Vaere, in her description of 1975, pointed towards watercolour backdrops to the illustrations that seem to have been written over by the title headings. There are indeed instances where this seems to be the case (e.g. 9v, 10v). However, there are also illuminations where the paint clearly runs over the title heading (e.g. 7v, 21r, 30r, 34r).

Lemaire-De Vaere may have been misled by the fact that the backdrops were painted in a thinned-down watercolour paint, which does not block out the title headings, whereas a next layer in thicker paint, used for example for the clothing of some of the figures depicted, does make them (nearly) invisible (see for example f. 36r, where the foot of the counsellor next to Duke John blocks out the $h$ in hertoge, whereas the lighter backdrop does not. In some instances, the backdrop also seems to follow the space filled (or not filled) by the title heading, which could point to the fact that it was put in after the text (e.g. 21r, 60v-61r).

We are inclined to follow Willems' assumption that the text was put in first, followed by the illuminations. This order of business would align more with the empty state of IV 685, which contains only text but was obviously intended to be illuminated in the same way as IV 684. Both processes must have followed each other closely in time, but it remains unclear why IV 685 was never finished.

The illuminations are well-known in that they figure relatively often as illustrations of the medieval history of Brabant, not only in scholarly publications, but also in more widely accessible media such as Wikipedia. They are in fact the only consecutive series of illustrations of a Middle Dutch Brabantine chronicle manuscript, and figure among the rare examples of illustrated Middle Dutch manuscript chronicles generally. Contrary to the lavish manuscript tradition of some of the Old French material (e.g. the Froissart manuscripts), Middle Dutch chronicle codices are generally modest and unillustrated. ${ }^{32}$ Manuscript IV 684, then, is a notable exception, and has received general acclaim among scholars, even if the illustrations themselves are not spectacular. Lemaire characterised them as 'pretentieloos en naïef' [mod-

(32) There is the notable exception of Jacob van Maerlant's Spiegel historiael, which has been preserved in a splendid copy dating to the fourteenth century: Ms. Den Haag, Koninklijke Bibliotheek, KA XX. 


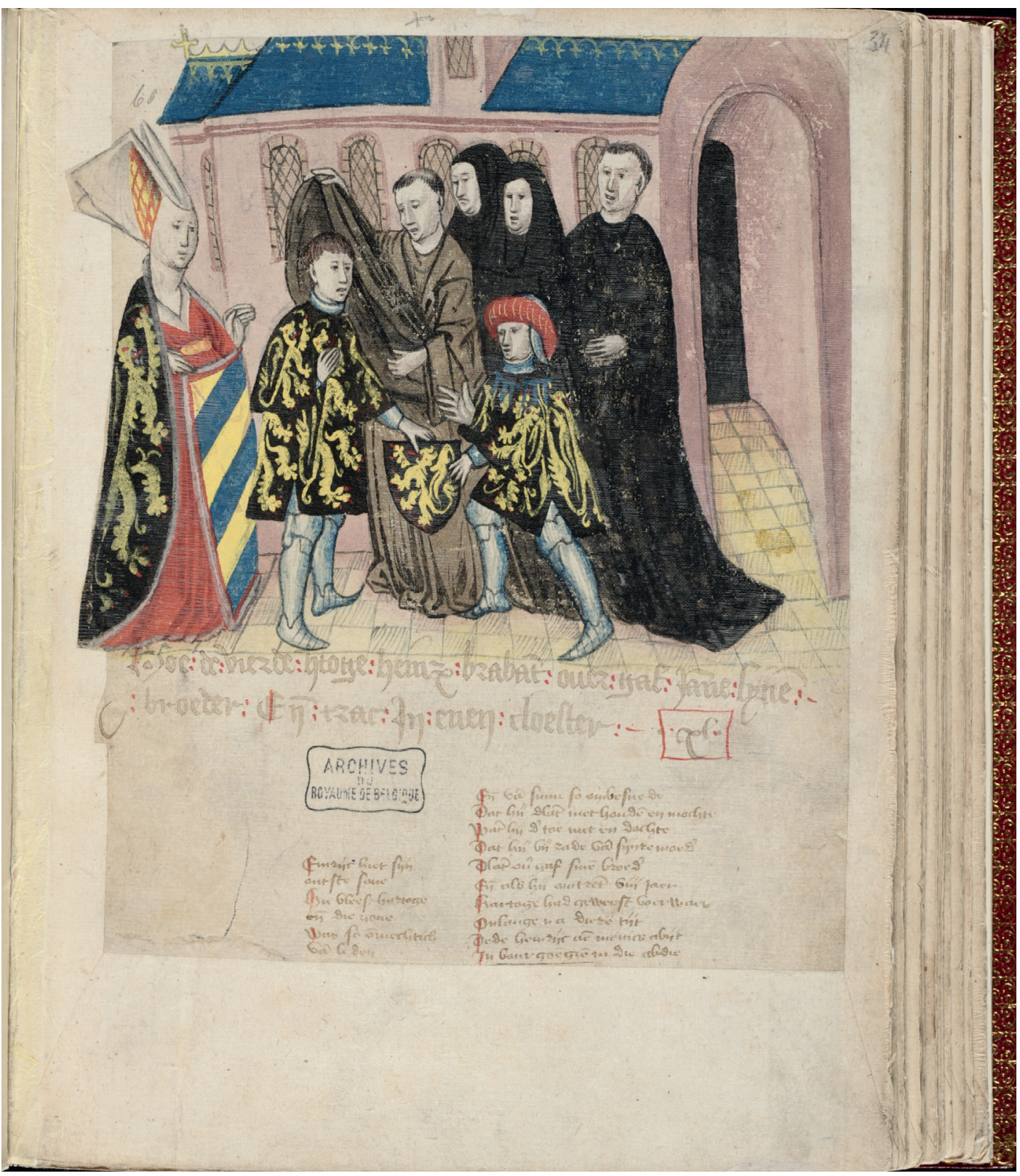

Fig. 3: The robe of Adelaide of Burgundy is painted over the initial $h$, IV 684, fol. 34r.

est and unsophisticated], while sometimes presenting a striking sense of realism. ${ }^{33}$ Indeed, when compared to contemporaneous illuminations, for example in manuscripts intended for the Burgundian court and its immediate circle, the illuminations are far less skilful. Even

(33) Lemaire-De Vaere, "Jan van Boendale: Brabantsche yeesten," 59. The French has a more negative connotation, where the illustrations are called 'frustes, parfois malhabiles' [crude, sometimes unskillful], LemaireDe Vaere, "Jan van Boendale: Brabantsche yeesten [French]," 57. 


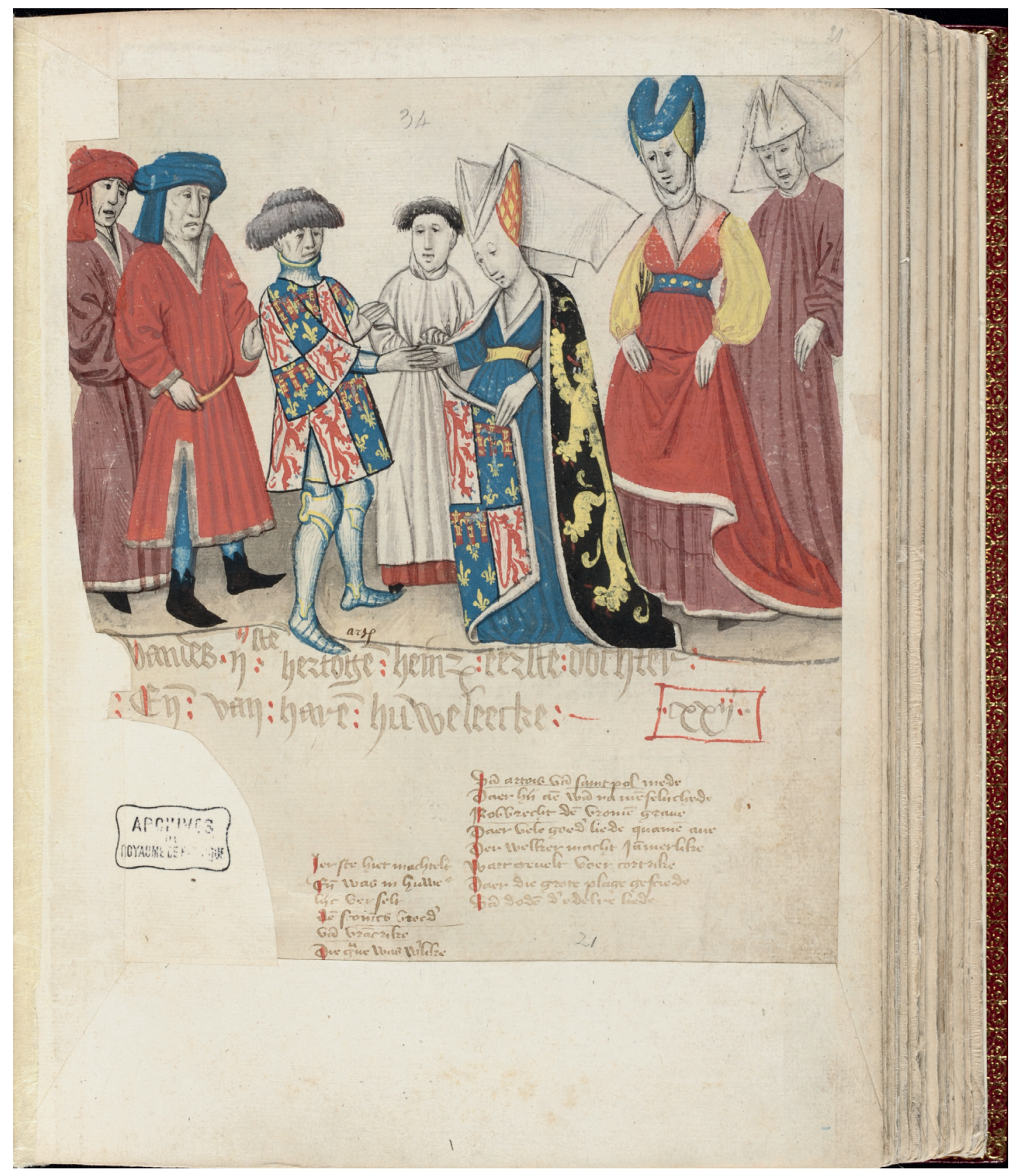

Fig. 4: Backdrop painted around the title heading; IV 684, fol. $21 \mathrm{r}$.

books of hours produced for more modest ends, can be said to answer more to the fashion of manuscript illumination of the period, than this Brabantine chronicle does. ${ }^{34}$ The illumi-

(34) An amply illustrated recent overview of southern Netherlandish illumination art is: Zuid-Nederlandse miniatuurkunst: de mooiste verluchte handschriften in Nederlands bezit, ed. Anne-Margreet W. As-Vijvers \& 
nations have no borders at all, are larger in size and more numerous than is customary. In their placement over the chapter headings and uneven size, they even present an impression of hastiness, if not sloppiness. In spite of this, they are attractive for their vivid depiction of combat, their expressive faces and their detailed heraldry. In what follows, we will look at some of the illustrations in more detail and present a general idea of the illumination programme.

Depending how one decides to count, there are around 70 illustrations throughout manuscript IV 684, which have been placed above the text, although occasionally a few lines of text were written down in the upper left corner of the page (e.g. 39r, 39v, 43r, 49r). Some illustrations are spread over two pages, e.g. Godfrey the Bearded with his children $(5 \mathrm{v}-6 \mathrm{r})$, the foundation of the abbey of Affligem $(6 \mathrm{v}-7 \mathrm{r})$, John I of Brabant and his brother Godfrey kneeling before king Louis IX of France $(42 \mathrm{v}-43 \mathrm{r})$, a tournament in England $(43 \mathrm{v}-44 \mathrm{r})$ and the hanging of Pierre de la Broce at Montfaucon (45v-46r). The depiction of the Battle of Worringen in $1288(60 \mathrm{v}-61 \mathrm{r})$ even occupies two full pages offering only space for a few lines of text at the bottom. In most, if not all cases the illustration also marks the beginning of a new chapter. ${ }^{35}$ In terms of colours, the illuminator seems to have preferred two shades of red (one bright red and the other pinkish), deep blue and a soft yellowish tone for the characters, together with a bluish grey for the knights' armour. A leather-like brown tone appears increasingly from about halfway into the codex. ${ }^{36}$ Buildings are coloured rosy with deep blue rooftops.

Some of the illustrations look alike, as the artist seems to have used recurrent compositions for similar events in Brabantine history. As the Brabantsche yeesten focuses on the Brabantine dynasty and, therefore, the succession of Dukes, marriages are a prominent part of the narrative, and therefore of the illustrations. Fifteen chapters in ms. IV 684 are accompanied by a marital scene, where generally the couple is depicted centre stage surrounded by a varying number of bystanders. Both bride and groom are clad in their respective heraldic coats of arms, with the former taking the double heraldry of the proposed matrimony, on either side of her cloak. Other ceremonial or official meetings show the same basic lay-out, e.g. Henry II of Brabant refusing the German crown (24v) or Henry IV of Brabant renouncing the throne in favour of John I (34r and 40r).

While the subsequent Dukes occupy the central role, the presence of bystanders in nearly every scene is interesting. Possibly, the artist wanted to provide a visual depiction of the fact that the Duke was surrounded by a courteous retinue and that his decisions were guided by counsellors. As the characters in most cases remain anonymous, any assumptions at this

Anne S. Korteweg (Utrecht: Museum Catharijneconvent; Zwolle: WBooks; Den Haag: Koninklijke Bibliotheek, 2018). The English translation, by the same publishing house, is entitled: Splendour of the Burgundian Netherlands: southern Netherlandish illuminated manuscripts in Dutch collections.

(35) In some cases, this can be debated, e.g. a series of coats of arms on $29 \mathrm{v}$ which illustrates text starting on $30 \mathrm{r}$.

(36) From 40r onwards, the ground adopts a slightly darker leather brown tone, which is used from then on also in the bystanders' clothing. 


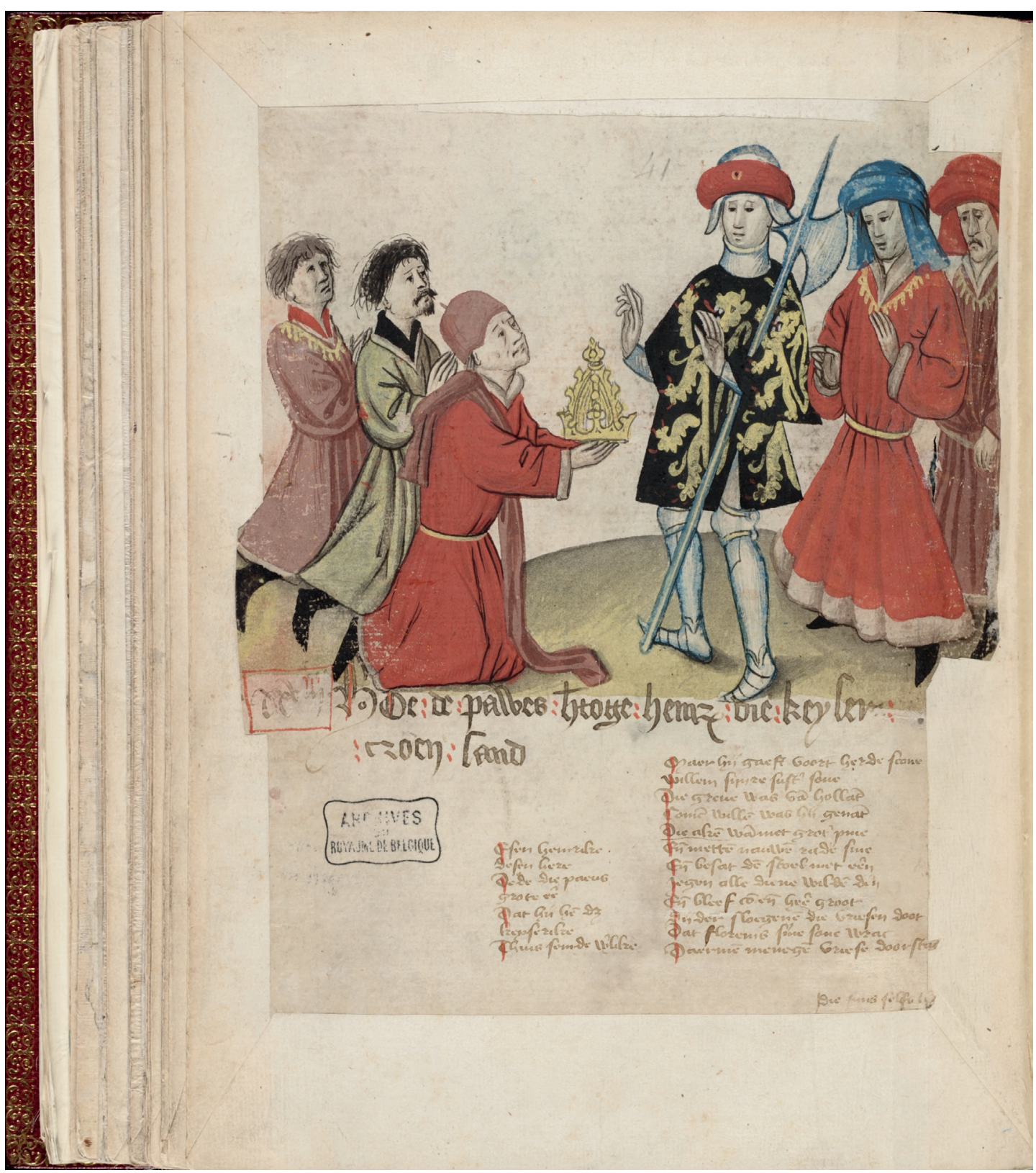

Fig. 5: Henry II of Brabant refusing the crown of the Romans; IV 684, fol. $24 \mathrm{v}$.

point remain hypothetical. Perhaps a detailed study of the costumes will bear fruit in the future, as a truthful depiction of ceremonial dress may shed light on the role of bystanders.

Another recurring composition is the depiction of battle scenes, with densely crowded battlefields. Not counting in nobles, who wear distinctive garments adorned with heraldic signs, this type of scene typically consists of armoured men occupied in a violent confrontation. Indeed, blood often runs over breastplates and from under helmets; detached body 
parts and abandoned weaponry illustrate the battle's fierceness (e.g. 15v, 18v, 31v, and the famous depiction of the battle of Worringen, 60v-61r). The compositions are not identi$\mathrm{cal}$, although we can point at instances where the illuminator clearly reuses elements from other illustrations. For instance, the depictions of the battle of Montenaken (15v) and the crusade against the Stedingen heretics (18v) both offer the usual crowded battlefield. In both pictures, a defeated enemy lies down on the foreground on the right-hand side. Their arms and legs are positioned almost identically. In this case the similarity is not coincidental, for just above this man's head stands another knight lifting with both hands above his head a sword, ready to slash an enemy into two. ${ }^{37}$ Interestingly, as the fight against the Stedingers was considered a crusade, the north German insurgents have been depicted as Muslims, with turbans and curved swords.

As the composition of many of the scenes is largely generic, their interpretation depends mainly from the heraldic elements and other details representing rank (e.g. clothing: crowns, bishop's mitres, uniforms, etc.), which have been carried out with a surprising attention to detail. Note the royal French crown (e.g. 43r), sometimes even added to the female headwear of Brabantine brides (e.g. 45r, 48v), or the distinctly German (imperial) crown in the depiction of William of Holland as king of the Germans (25r). Lesser nobles are recognisable by their heraldic signs, in which the artist was careful enough to add marks of cadency (NL breuken / FR brisures) (e.g. 16v, 30r, 33r, 34r). Cities as well, have been depicted in an interchangeable way and differ from each other only in the coat of arms above their gates or in banners - with the exception of two depictions of Aachen featuring buildings resembling the cathedral with a little imagination (53v, 54v). While the heraldry certainly deserves a more thorough look, we have the impression that the artist has a fairly good knowledge of nobility and its heraldic signs, not only those of Brabant and its neighbouring lands, but also those of England and France for example. This knowledge of course bears the distinct mark of the fifteenth century, as contemporary heraldry is projected back into a past when heraldic signs had not developed into full form. A good example is the depiction of the Grimbergen wars (mid-twelfth century) which has the combatants sporting their fifteenth-century banners $(10 \mathrm{v}) .{ }^{38}$ The illustrator based his work not only on the accompanying text, but was certainly aware of the wider context of Brabantine historiography. In some cases, the detailed heraldry in the illuminations is not mentioned in the text in the manuscript. A case in point is a chivalric tournament in England in which John I of Brabant and the most notable knights of the Duchy jousted against English opponents (43v-44r).

(37) Another example may be two sieges with cannons - incidentally also an anachronism in the conflicts depicted. See fols 9v (siege of Grimbergen) and 23v (siege of Cologne). The cannons are mirrored.

(38) This aligns with the textual source that probably inspired this part of the chronicle, the anonymous verse epic Grimbergsche oorlog, where the heraldic description of combatants presents a more modern state of heraldlry, see W. Haverals, "Heraldisch vakmanschap in 'De Grimbergse oorlog," Queeste 23 (2016) 1: 22-36. 


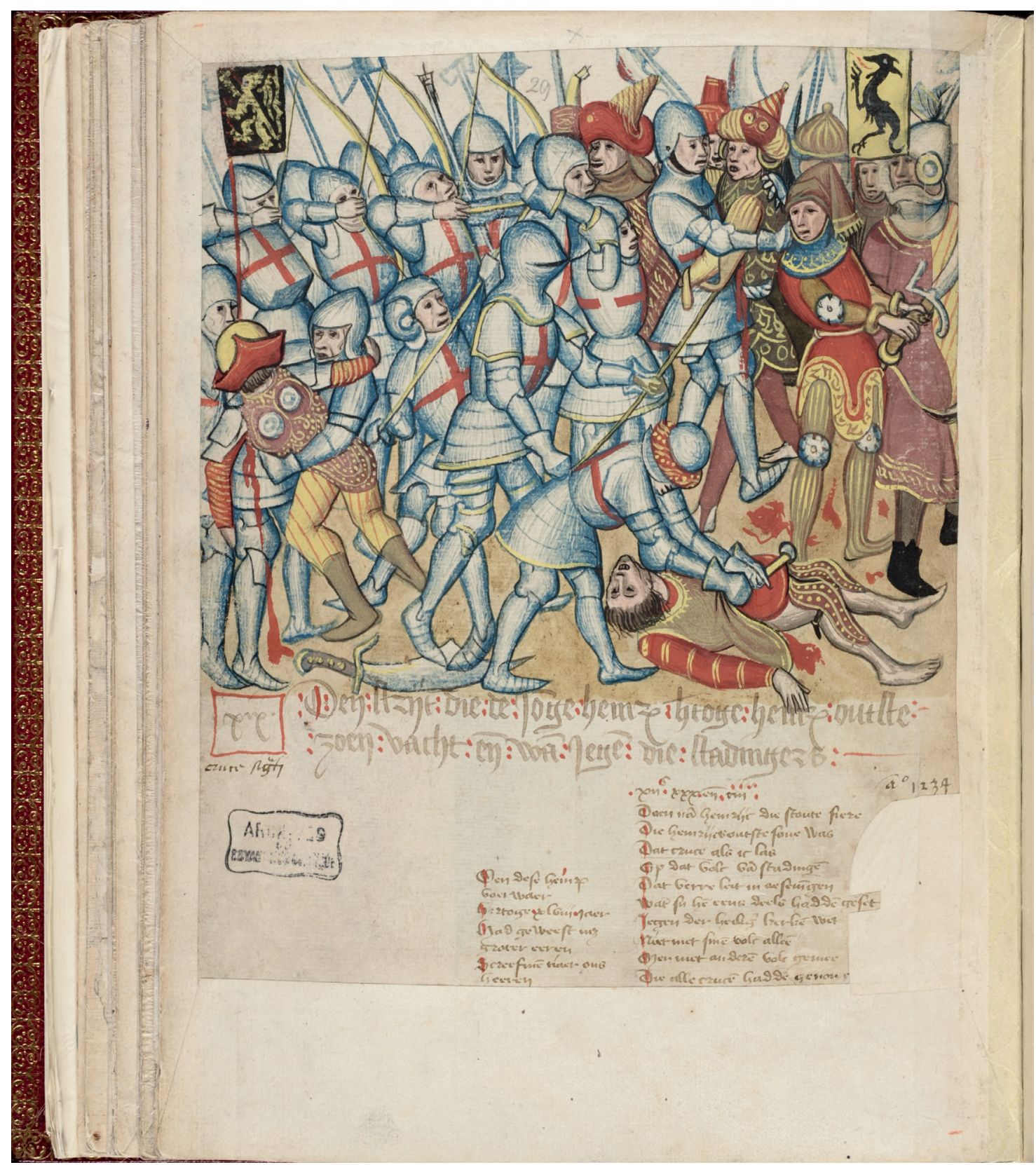

Fig. 6: The crusade against Stedingen; IV 684, fol. 18v.

The detailed depiction of the heraldic signs of the combatants is not in line with the accompanying text, where the joust is mentioned merely in passing (see below). Also, the heraldry in question represents a later stage of English nobility than it is supposed to, placing the tournament heraldically under Edward III rather than under Edward I. This might be a reference to the Anglo-French disputes, as Damen has suggested, or may well be an 


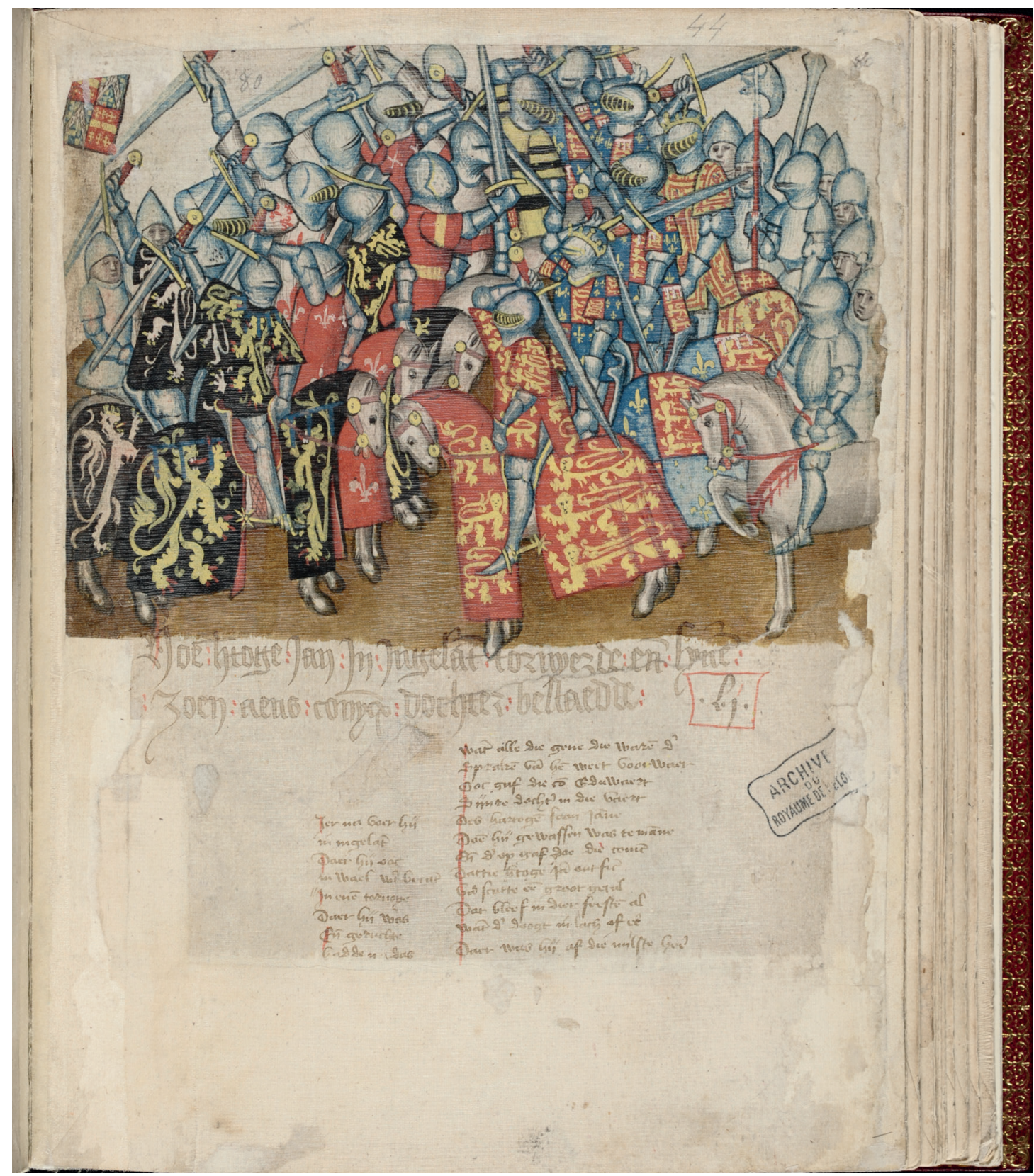

Fig. 7: John I and his knights joust against English opponents; IV 684, fol. 44r.

indication that the artist worked with a heraldic source such as a roll of arms that presented a fourteenth- rather than a thirteenth-century state of English nobility. ${ }^{39}$ In the depiction of the Battle of Worringen (1288) as well, the amount of detail in the illumination, especially

(39) See M. Damen "Heraldische plaagstoot in een middeleeuws handschrift?," on the research blog burgundiannobility.wordpress.com [09/07/2018], published 17 November 2014. 
in terms of heraldry, is nowhere to be found in the text of the manuscript. Here too, the artist may have based his work on other sources, such as the Slag bij Woeringen, a detailed fourteenth-century literary account of this battle by Jan van Heelu, which devotes a lot of attention to the heraldry of the combatants. ${ }^{40}$

\section{EPILOGUE}

In the early forties of the fifteenth century, a Brabantine scribe copied books four and five of Jan van Boendale's Brabantsche Yeesten into two volumes. The first volume was lavishly illuminated, and its illustrations have found their way into many scholarly publications where they serve as the go-to collection of iconography dealing with the history of Brabant. Strangely, the manuscript context in which they can be found has received very scarce attention. This article has made an attempt to open up research into the illuminated ms. IV 684 and its unfinished counterpart ms. IV 685. We have further detailed the only description of the manuscripts and have provided a survey of the illuminations. In addition, the following appendix includes a list of all illustrations in ms. IV 684, supplemented by the chapter titles, folio and page numbers and an indication of when the depicted events occurred. It is accompanied by an index listing all identifiable characters. We hope that this contribution, along with the online access to the manuscripts provided by the Royal Library, will spur researchers onto new discoveries.

\section{APPENDIX 1: LIST OF ILLUSTRATIONS}

This list contains a complete overview of all the illustrations that can be found in Brussels, KBR, IV 684. We provide a diplomatic transcription of the chapter headings in the manuscript, with their chapter numbers and a translation in square brackets, followed by a short description of the illustration and a reference to folio and page numbers. ${ }^{41}$ The last column in some cases indicates the year in which events occurred. ${ }^{42}$

(40) See for an introduction J. Goossens, "5 juni 1288: Hertog Jan I van Brabant wint de Slag bij Woeringen: de glorie van de ridder-dichter," in Nederlandse literatuur: een geschiedenis, ed. M.A. Schenkeveld-van der Dussen et al. (Groningen: Martinus Nijhoff Uitgevers, 1993), 41-6. The text by Jan van Heelu has been edited by J.-F. Willems, Rymkronyk van Jan van Heelu betreffende den slag van Woeringen van het jaer 1288 (Brussels: Hayez, 1862). See online: https://www.dbnl.org/tekst/heel001jfwi01_01/ [11/07/2018].

(41) Following T. Mertens, Richtlijnen voor de uitgave van middeleeuwse verzamelhandschriften uit de Nederlanden; geredigeerd onder verantwoordelijkheid van de projectcommissie "Middeleeuwse Verzamelhandschriften uit de Nederlanden" (Hilversum: Verloren, 1994).

(42) For a general overview of Brabantine history, see Geschiedenis van Brabant: van het hertogdom tot heden, ed. R. Van Uytven et al. (Zwolle: Waanders, 2004). 


\begin{tabular}{|c|c|c|c|c|c|}
\hline Ch. & Heading in ms. IV 684 & Image depiction & fol. & pp. & Year \\
\hline & $\begin{array}{l}\text { Dordena } n \text { cie vanden vierde } n \text { boecke } \\
\text { [The arrangement of the fourth book] }\end{array}$ & Monastery with two monks in the doorstep. & & 1 & - \\
\hline 1 & $\begin{array}{l}\text { Hoe godeuaert metten baerde regn- } \\
\text { eerde ende sijn doot } \\
\text { [How Godfrey the Bearded ruled and } \\
\text { his death] }\end{array}$ & $\begin{array}{l}\text { Godfrey I lies deceased in a coffin covered } \\
\text { in black cloth with a red cross and four } \\
\text { Brabantine lions. Four mourners in black } \\
\text { cloaks, remeniscent of sculpted pleurants, } \\
\text { and four carriers of torches, also in black. }\end{array}$ & $5 \mathrm{r}$ & 2 & 1139 \\
\hline 2 & $\begin{array}{l}\text { Van godeuaerts mette } n \text { baerde vijf } \\
\text { kinderen } \\
\text { [Of Godfrey the Bearded's five } \\
\text { children] }\end{array}$ & $\begin{array}{l}\text { Godfrey's five children. From left to right: } \\
\text { Godfrey II of Brabant, Henry, Adeliza of } \\
\text { England, Ida of Cleves and Clarissa. }\end{array}$ & $5 v-6 r$ & $3-4$ & 1139 \\
\hline \multirow[t]{2}{*}{3} & $\begin{array}{l}\text { Hoe haffelge } m \text { eerst began } \\
\text { [The beginnings of Affligem] }\end{array}$ & $\begin{array}{l}\text { Monk preaching before an audience of } \\
\text { knights and civilians, all male. }\end{array}$ & 6v & 5 & - \\
\hline & & $\begin{array}{l}\text { Archbishop Anno II of Cologne absolving } \\
\text { five knights and ordering them to build a } \\
\text { monastery [= Affligem]. }\end{array}$ & $7 \mathrm{r}$ & 6 & 1062 \\
\hline 4 & $\begin{array}{l}\text { Van godeuaerde godeuaerds metten } \\
\text { baerde zoen } \\
\text { [Of Godfrey, son of Godfrey the } \\
\text { Bearded] }\end{array}$ & $\begin{array}{l}\text { Marriage between Godfrey II and Lutgardis } \\
\text { of Sulzbach. Among the crowd is the Ger- } \\
\text { man Emperor, possibly Conrad III who was } \\
\text { married to Lutgardis' sister. }\end{array}$ & & 7 & 1139 \\
\hline 5 & $\begin{array}{l}\text { Hoe heinric van limborch trac op } \\
\text { godeuaerde met machte } \\
\text { [How Henry of Limburg waged war } \\
\text { against Godfrey] }\end{array}$ & $\begin{array}{l}\text { Army of Henry I of Limburg on horseback. } \\
\text { Banners of Limburg and Luxembourg. }\end{array}$ & $8 \mathrm{r}$ & 8 & \\
\hline 6 & $\begin{array}{l}\text { Hoe godeuaert sintrude } n \text { belach ende } \\
\text { hoe sij hem in hant quamen ende } \\
\text { hem hulden } \\
\text { [How Godfrey lay siege to Sint- } \\
\text { Truiden and how they let him in and } \\
\text { paid him hommage] }\end{array}$ & $\begin{array}{l}\text { Godfrey II and his army outside the city } \\
\text { of Sint-Truiden, negotiating a peaceful sur- } \\
\text { render of the city. The city bears its coat of } \\
\text { arms. }\end{array}$ & $8 \mathrm{v}$ & 9 & \\
\hline 7 & $\begin{array}{l}\text { Vanden derden hertoge godeuaert } \\
\text { [Of the third Duke Godfrey] }\end{array}$ & $\begin{array}{l}\text { Godfrey III in his cradle, accompanied by } \\
\text { his guardians. Bystanders pledge allegiance } \\
\text { to the young Duke. }\end{array}$ & $9 \mathrm{r}$ & 10 & 1142 \\
\hline 8 & $\begin{array}{l}\text { Hoe die brabantsche baronen wonnen } \\
\text { die borch te grembergen } \\
\text { [How the barons of Brabant won } \\
\text { Grimbergen castle] }\end{array}$ & $\begin{array}{l}\text { Siege of the stronghold of Grimbergen. } \\
\text { Canons and archers shoot at the guarded } \\
\text { walls. The besieging army carries banners of } \\
\text { Beersel, Gaasbeek and Diest. The besieged } \\
\text { under banners of Grimbergen and Hoorne. }\end{array}$ & $9 \mathrm{v}$ & 11 & 1142 \\
\hline 9 & $\begin{array}{l}\text { Hoe de derde godeuaert te grember- } \\
\text { gen den strijt want inder wiegen } \\
\text { [How Godfrey III won the battle in } \\
\text { Grimbergen in his cradle] }\end{array}$ & $\begin{array}{l}\text { Scene from the battle of Ransbeek depict- } \\
\text { ing a Brabantine victory. Godfrey III in his } \\
\text { cradle between two trees with a female figure } \\
\text { - possibly intended to depict his mother } \\
\text { - behind him while knights are immersed } \\
\text { in a bloody battle. Banners of Brabant, Di- } \\
\text { est, Gaasbeek, Wezemaal, Grimbergen and } \\
\text { Mechelen. }\end{array}$ & $10 \mathrm{v}$ & 13 & 1142 \\
\hline 10 & $\begin{array}{l}\text { Thuwelijcke vanden derden hertoge } \\
\text { godeuaerde } \\
\text { [The marriage of Godfrey III] }\end{array}$ & $\begin{array}{l}\text { Marriage between Godfrey III and Margaret } \\
\text { of Limburg. }\end{array}$ & $11 \mathrm{r}$ & 14 & 1155 \\
\hline 11 & $\begin{array}{l}\text { Tweeste huweleeck vanden derden } \\
\text { hertoge godeuaerde } \\
\text { [Second marriage of Godfrey III] }\end{array}$ & $\begin{array}{l}\text { Marriage between Godfrey III and Imagina } \\
\text { of Loon. }\end{array}$ & $12 \mathrm{r}$ & 16 & 1180 \\
\hline
\end{tabular}




\begin{tabular}{|c|c|c|c|c|c|}
\hline Ch. & Heading in ms. IV 684 & Image depiction & fol. & pp. & Year \\
\hline 12 & $\begin{array}{l}\text { Van hertoge heinric des derden go- } \\
\text { deuaerts zoen die te coellen sterf ende } \\
\text { van sine huweleecke } \\
\text { [Of Duke Henry, son of Godfrey } \\
\text { III, who died in Cologne and of his } \\
\text { marriage] }\end{array}$ & $\begin{array}{l}\text { Marriage between Henry I of Brabant and } \\
\text { Matilda of Boulogne. }\end{array}$ & $13 \mathrm{v}$ & 17 & 1179 \\
\hline 13 & $\begin{array}{l}\text { Den anderen huweleke van hertoghe } \\
\text { heinric voirscreuen } \\
\text { [The second marriage of Duke } \\
\text { Henry] }\end{array}$ & $\begin{array}{l}\text { Marriage between Henry I of Brabant and } \\
\text { Mary of France. }\end{array}$ & $13 \mathrm{v}$ & 19 & 1213 \\
\hline 15 & $\begin{array}{l}\text { Hoe hertoge heinric ludicke wan } \\
\text { [How Duke Henry won Liège] }\end{array}$ & $\begin{array}{l}\text { Siege of Liège. Henry I sporting a halberd, } \\
\text { while his knights enter the city. Liège crest } \\
\text { on the city walls. Banners of Brabant, Loon, } \\
\text { Diest, Gaasbeek and Wezemaal. }\end{array}$ & $14 \mathrm{v}$ & 21 & 1212 \\
\hline 16 & $\begin{array}{l}\text { Den strijt te montenaken } \\
\text { [The battle in Montenaken] }\end{array}$ & $\begin{array}{l}\text { Battle of Montenaken. Knights attacking } \\
\text { each other. Banners of Liège, Loon, Brabant, } \\
\text { Geten/Jauche, Gaasbeek, Wezemaal and } \\
\text { Diest. }\end{array}$ & $15 \mathrm{v}$ & 23 & 1213 \\
\hline 17 & $\begin{array}{l}\text { Hoe die graue ferrant belach die stad } \\
\text { van bruessel met vele groter heren } \\
\text { [How Count Ferdinand lay siege to } \\
\text { Brussels with a great number of high } \\
\text { lords] }\end{array}$ & $\begin{array}{l}\text { Siege of Brussels led by Ferdinand of Portugal } \\
\text { (as jure uxoris Count of Flanders). Army of } \\
\text { knights. From left to right: William I of Hol- } \\
\text { land, William Longespée, Count of Salisbury, } \\
\text { halfbrother of the King of England }{ }^{43} \text { The } \\
\text { coat of arms has erroneously remained undif- } \\
\text { ferenced and the character is crowned), Fer- } \\
\text { dinand of Portugal and Renaud of Boulogne. } \\
\text { Kneeled in surrender Henry I of Brabant and } \\
\text { his two sons, the later Henry II and Godfrey } \\
\text { of Louvain-Gaasbeek. The coat of arms on } \\
\text { the city walls is painted in plain red. }\end{array}$ & $16 \mathrm{v}$ & 25 & 1213 \\
\hline 18 & $\begin{array}{l}\text { Vande } n \text { strijde te boevijnes } \\
\text { [Of the battle in Bouvines] }\end{array}$ & $\begin{array}{l}\text { Marriage between Holy Roman emperor } \\
\text { Otto IV and Henry I of Brabant's daughter } \\
\text { Maria, in the presence of Henry I and prob- } \\
\text { ably his second wife Mary of France. }\end{array}$ & $17 \mathrm{v}$ & 27 & 1214 \\
\hline 19 & $\begin{array}{l}\text { Den strijt die de jonge hertoge heinric } \\
\text { hertoge heinrics outste zoen vacht } \\
\text { ende wan jegen die stadingers } \\
\text { [The battle that the young Duke Hen- } \\
\text { ry, eldest son of Duke Henry fought } \\
\text { and won against the Stadingers] }\end{array}$ & $\begin{array}{l}\text { Crusade against Stedingen. Battle scene with } \\
\text { harnessed knights with red crusader's crosses, } \\
\text { fighting the Stadingers, who are depicted in } \\
\text { clothing normally associated with muslims. } \\
\text { Banners of Brabant and Stedingen (fic- } \\
\text { tional?). }\end{array}$ & $18 \mathrm{v}$ & 29 & $\begin{array}{l}1233- \\
1234\end{array}$ \\
\hline 20 & $\begin{array}{l}\text { Des oude } n \text { hertoge heinrics doot } \\
\text { [The death of the old Duke Henry] }\end{array}$ & $\begin{array}{l}\text { Henry I's funeral. His coffin is covered in } \\
\text { black cloth with a red cross and several Bra- } \\
\text { bantine lions. Monks are praying for him. } \\
\text { Seven weepers in black. Two torches and the } \\
\text { city of Louvain, with its coat of arms, in the } \\
\text { background. }\end{array}$ & $19 \mathrm{v}$ & 30 & 1235 \\
\hline
\end{tabular}

(43) In 1213, John Lackland was king of England. None of his legitimate brothers were alive anymore. William Longespée (c. 1176-1226), count of Salisbury, was an illegitimate child of Henry II and commanded the English fleet in the Battle of Damme (1213), where he destroyed a French fleet preparing to invade England. Henry I of Brabant supported the French king Philip II. 


\begin{tabular}{|c|c|c|c|c|c|}
\hline Ch. & Heading in ms. IV 684 & Image depiction & fol. & pp. & Year \\
\hline 21 & $\begin{array}{l}\text { Hoe dander heinric hertoge wert ende } \\
\text { sijn huwelijck } \\
\text { [How Henry II became Duke and of } \\
\text { his marriage] }\end{array}$ & $\begin{array}{l}\text { Marriage between Henry II of Brabant and } \\
\text { Maria of Swabia. Henry is also sworn in as } \\
\text { Duke of Brabant, clad in his coat of arms } \\
\text { and a black overcoat. }\end{array}$ & $20 \mathrm{r}$ & [32] & 1215 \\
\hline 22 & $\begin{array}{l}\text { Vandes } \text { II }^{\text {sten }} \text { hertogen heinrics eerste } \\
\text { dochter Ende van hare } n \text { huweleecke } \\
\text { [Of Henry II's first daughter and of } \\
\text { her marriage] }\end{array}$ & $\begin{array}{l}\text { Marriage between Henry II of Brabant's } \\
\text { daughter Matilda and Robert I of Artois } \\
\text { (coat of arms with Artois and Limburg (?)). }\end{array}$ & $21 \mathrm{r}$ & 34 & 1237 \\
\hline 23 & $\begin{array}{l}\text { Vander ander dochter van haren } \\
\text { huweleecke ende haer doot } \\
\text { [Of the second daughter, her marriage } \\
\text { and her death] }\end{array}$ & $\begin{array}{l}\text { Beheading of Henry II of Brabant's daughter } \\
\text { Mary by her husband Louis II of Bavaria. } \\
\text { Bystanders in dismay. }\end{array}$ & $21 \mathrm{v}$ & 35 & 1256 \\
\hline 24 & $\begin{array}{l}\text { Vander derder dochter ende va } n \text { haren } \\
\text { huweleecke } \\
\text { [Of the third daughter and her mar- } \\
\text { riage] }\end{array}$ & $\begin{array}{l}\text { Marriage between Henry II of Brabant's } \\
\text { daughter Beatrice and Henry Raspe of } \\
\text { Thuringia. }\end{array}$ & $22 \mathrm{r}$ & 36 & 1241 \\
\hline 25 & $\begin{array}{l}\text { Hoe haer die vierde dochter begaf } \\
\text { inden cloester tshertogen dale } \\
\text { [How the fourth daughter entered the } \\
\text { convent of Valduc] }\end{array}$ & $\begin{array}{l}\text { Convent of Hertogendal (Valduc) with } \\
\text { Henry II of Brabant's daughter Margaret } \\
\text { entering as abbess. }\end{array}$ & $22 \mathrm{v}$ & 37 & c. 1235 \\
\hline 26 & $\begin{array}{l}\text { Des anderen heinrics tweesten hu- } \\
\text { welijck } \\
\text { [The second marriage of Henry II] }\end{array}$ & $\begin{array}{l}\text { Henry II's second marriage with Sophie of } \\
\text { Thuringia. }\end{array}$ & $23 r$ & 38 & 1240 \\
\hline 27 & $\begin{array}{l}\text { Hoe de tweeste hertoge heinric coelen } \\
\text { belach } \\
\text { [The siege of Cologne by Duke } \\
\text { Henry II] }\end{array}$ & $\begin{array}{l}\text { Siege of Cologne by Henry II of Brabant. } \\
\text { Archers and canons firing at the city walls. } \\
\text { To the left knights are resting in tents. Ban- } \\
\text { ners of Brabant and Cologne (city). }\end{array}$ & $23 v$ & 39 & \\
\hline 28 & $\begin{array}{l}\text { Hoe de pawes hertoge heinric die } \\
\text { keyser croen sand } \\
\text { [How the Pope sent Duke Henry the } \\
\text { Imperial crown] }\end{array}$ & Henry II refuses the German crown. & $24 \mathrm{v}$ & 41 & 1247 \\
\hline 29 & $\begin{array}{l}\text { Hoe graue willem va } n \text { hollant de } \\
\text { keyser croen ontfinc } \\
\text { [How Count William of Holland } \\
\text { received the Imperial crown] }\end{array}$ & $\begin{array}{l}\text { William II of Holland is crowned King of } \\
\text { the Germans by Konrad von Hochstaden, } \\
\text { archbishop of Cologne and by Arnold II } \\
\text { von Isenburg (?) archbishop of Trier. On the } \\
\text { right stands his wife Elisabeth of Brunswick. }\end{array}$ & $25 \mathrm{r}$ & 42 & 1247 \\
\hline 30 & $\begin{array}{l}\text { Hoe die bisscop van ludicke de twe- } \\
\text { este } n \text { hertoge heinric te camp hiesch } \\
\text { Ende he } m \text { den hantscoe gaf } \\
\text { [How the Bishop of Liège challenged } \\
\text { Duke Henry II to a fight, handing } \\
\text { him a gauntlet] }\end{array}$ & $\begin{array}{l}\text { Bishop of Liège (Henry III of Guelders) } \\
\text { handing over Henry II of Brabant a gaunt- } \\
\text { let. }\end{array}$ & $26 \mathrm{r}$ & 44 & c. 1247 \\
\hline 31 & $\begin{array}{l}\text { Hoe de tweeste hertoge heinric te } \\
\text { loeuen socht enen kempenjoen } \\
\text { [How Duke Henry II sought out a } \\
\text { champion in Louvain] }\end{array}$ & $\begin{array}{l}\text { Champion kneeling down before Henry II } \\
\text { just outside Louvain. }\end{array}$ & $27 \mathrm{r}$ & 46 & c. 1247 \\
\hline 32 & $\begin{array}{l}\text { Vande } n \text { campe die te ludicke gesciede } \\
\text { [Of the fight in Liège] }\end{array}$ & $\begin{array}{l}\text { Two champions clad in red fighting in a } \\
\text { fenced square. Clubs are lying around. The } \\
\text { bishop of Liège and duke Henry II of Bra- } \\
\text { bant are amongst the enthusiastic spectators. }\end{array}$ & $28 \mathrm{r}$ & 48 & c. 1247 \\
\hline
\end{tabular}




\begin{tabular}{|c|c|c|c|c|c|}
\hline Ch. & Heading in ms. IV 684 & Image depiction & fol. & pp. & Year \\
\hline 34 & $\begin{array}{l}\text { Vanden derden hertoge heinric Ende } \\
\text { van sinen huweleke } \\
\text { [Of Duke Henry III and of his mar- } \\
\text { riage] }\end{array}$ & $\begin{array}{l}\text { Marriage between Henry III of Brabant and } \\
\text { Adelaide of Burgundy. }\end{array}$ & $29 \mathrm{r}$ & 50 & 1251 \\
\hline 35 & $\begin{array}{l}\text { Vandes derden hertoge heinrijcs } \\
\text { magen } \\
\text { [Of Duke Henry III's relatives] }\end{array}$ & $\begin{array}{l}\text { Verso side: heraldic series depicting Henry } \\
\text { III's ancestors. Kingdoms of Jerusalem, } \\
\text { Bohemia, Leon. Counties/duchies of Brabant } \\
\text { (twice), Thuringia, Artois, Guelders. William } \\
\text { II of Holland's crest is missing, but he is } \\
\text { depicted on the recto side as King of the } \\
\text { Romans. } \\
\text { Recto side: Henry III of Brabant with his } \\
\text { sons Henry IV and John I. They are flanked } \\
\text { by Henry III's ancestors. Depicted are } \\
\text { emperors and kings, one of them Byzantine } \\
\text { emperor Emanuel I Komnenos. The German } \\
\text { kings or emperors mentioned in the text are } \\
\text { probably: Frederick Barbarossa, Philips of } \\
\text { Swabia, Frederick II of Hohenstaufen, Henry } \\
\text { of Hohenstaufen, William II of Holland. }\end{array}$ & $\begin{array}{l}29 \mathrm{v}- \\
30 \mathrm{r}\end{array}$ & $\begin{array}{l}51- \\
52\end{array}$ & c. 1260 \\
\hline 36 & $\begin{array}{l}\text { De doot van coninc willem van hol- } \\
\text { land } \\
\text { [The death of King William of Hol- } \\
\text { land] }\end{array}$ & $\begin{array}{l}\text { William II of Holland's death on a bat- } \\
\text { tlefield. Banners of Holland, the German } \\
\text { Empire and Frisia. }\end{array}$ & $31 \mathrm{v}$ & 55 & 1256 \\
\hline 37 & $\begin{array}{l}\text { Hoe hertoge heinric in hollant trac } \\
\text { ende floreys sinen neue vermombo- } \\
\text { erde } \\
\text { [How Duke Henry entered Holland } \\
\text { and became guardian of his nephew } \\
\text { Floris] }\end{array}$ & $\begin{array}{l}\text { Henry III of Brabant on horseback with his } \\
\text { knights, encountering a young Floris V of } \\
\text { Holland on foot. }\end{array}$ & $32 \mathrm{v}$ & 57 & 1256 \\
\hline 38 & $\begin{array}{l}\text { Vandes derden hertoge heinrics } \\
\text { kinderen } \\
\text { [Of Duke Henry III's children] }\end{array}$ & $\begin{array}{l}\text { Henry III of Brabant and Adelaide of } \\
\text { Burgundy's children. Depicted to the left } \\
\text { of Henry III are sons Godfrey, John I and } \\
\text { Henry IV. Depictd to the right of Adelaide } \\
\text { is daughter Mary. }\end{array}$ & $33 r$ & 58 & c. 1265 \\
\hline 40 & $\begin{array}{l}\text { Hoe de vierde hertoge heinric brabant } \\
\text { ouer gaf janne synen broeder Ende } \\
\text { trac in enen cloester } \\
\text { [How Duke Henry IV handed over } \\
\text { the Duchy to his brother John, and } \\
\text { entered a convent] }\end{array}$ & $\begin{array}{l}\text { Henry IV hands over to his brother John } \\
\text { I the coat of arms of Brabant in front of a } \\
\text { monastery, in the presence of their mother } \\
\text { and four monks. }\end{array}$ & $34 \mathrm{r}$ & 60 & 1267 \\
\hline 41 & $\begin{array}{l}\text { Hoe de graue van gelre ende de biss- } \\
\text { cop van ludicke brabant vermombor- } \\
\text { en wouden Ende dorloge van loeuen } \\
\text { [How the Count of Guelders and } \\
\text { the Bishop of Liège wanted to be } \\
\text { guardians over Brabant, and the war } \\
\text { of Louvain] }\end{array}$ & $\begin{array}{l}\text { Otto II, Count of Guelders, Henry III of } \\
\text { Guelders, Bishop of Liège and Henry I, } \\
\text { Landgrave of Hesse in dispute with Adelaide } \\
\text { of Burgundy, Duchess-regent of Brabant, } \\
\text { over guardianship over Henry IV. }\end{array}$ & $35 \mathrm{r}$ & 62 & c. 1267 \\
\hline 42 & $\begin{array}{l}\text { Des eerste hertoge jans huweleecke } \\
\text { [The marriage of Duke John I] }\end{array}$ & John I's marriage with Margaret of France. & $36 r$ & 64 & 1270 \\
\hline
\end{tabular}




\begin{tabular}{|c|c|c|c|c|c|}
\hline Ch. & Heading in ms. IV 684 & Image depiction & fol. & pp. & Year \\
\hline 43 & $\begin{array}{l}\text { Den tweeste } n \text { huweleecke vande } n \\
\text { eerste } n \text { hertoge Jan } \\
\text { [The second marriage of Duke John } \\
\text { I] }\end{array}$ & $\begin{array}{l}\text { John I's second marriage with Margaret of } \\
\text { Dampierre (Flanders). Standing behind John } \\
\text { are their sons John II and Godfrey. Daugh- } \\
\text { ters Margaret and Mary are positioned next } \\
\text { to their mother on the right. }\end{array}$ & $36 \mathrm{v}$ & 65 & 1273 \\
\hline 44 & $\begin{array}{l}\text { Hoe heinric van gaesbeeke mombor } \\
\text { wert ende na hem her beertout ende } \\
\text { her heinric van boutersem } \\
\text { [How Henry of Gaasbeek became } \\
\text { guardian, and after him Lord Berth- } \\
\text { out and Lord Henry of Boutersem] }\end{array}$ & $\begin{array}{l}\text { Contenders for the guardianship over Henry } \\
\text { IV of Brabant. From left to right: Henry } \\
\text { of Gaasbeek, Godfrey of Perwez, John I of } \\
\text { Brabant, Wouter V Berthout and Henry IV } \\
\text { of Boutersem (Brabant, differenced). }\end{array}$ & $37 \mathrm{r}$ & 66 & 1262 \\
\hline 45 & $\begin{array}{l}\text { vanden orloge va } n \text { wesemael } \\
\text { [Of the war of Wezemaal] }\end{array}$ & $\begin{array}{l}\text { Arnold III of Wezemaal with his army on } \\
\text { horseback before the gates of Louvain. Ban- } \\
\text { ner of Wezemaal. }\end{array}$ & $38 \mathrm{r}$ & 68 & 1266 \\
\hline 46 & $\begin{array}{l}\text { Hoe die bisscop heinric va } n \text { ludicke } \\
\text { mechle } n \text { belach } \\
\text { [How Bishop Henry of Liège lay siege } \\
\text { to Mechelen] }\end{array}$ & $\begin{array}{l}\text { The army of the Bishop of Liège (Henry III } \\
\text { of Guelders) before the gates of Mechelen. } \\
\text { Banners of Loon, Guelders and Liège. }\end{array}$ & $39 r$ & 70 & 1268 \\
\hline 47 & $\begin{array}{l}\text { HOe de vierde heinrijc te cortenberge } \\
\text { brabant ouer gaf voerde staten janne } \\
\text { synen broeder } \\
\text { [How Henry IV handed over the } \\
\text { Duchy to his brother, in Kortenberg] }\end{array}$ & $\begin{array}{l}\text { Henry IV of Brabant hands over a shield } \\
\text { with the coat of arms of Brabant to his } \\
\text { younger brother John I of Brabant. }\end{array}$ & $40 \mathrm{r}$ & 72 & 1267 \\
\hline 48 & $\begin{array}{l}\text { HOe dedele va } n \text { brabant haer leen } \\
\text { ontfingen Ende hoe her aernout ter } \\
\text { soenen quam } \\
\text { [How the nobles of Brabant received } \\
\text { their fiefs, and how Arnold came to } \\
\text { be reconciled] }\end{array}$ & $\begin{array}{l}\text { Nobles of Brabant pledging allegiance to } \\
\text { John I. Centre stage is Arnold III of Weze- } \\
\text { maal. }\end{array}$ & $41 \mathrm{r}$ & 74 & 1267 \\
\hline 49 & $\begin{array}{l}\text { Hoe hertoge jan Ende de graue van } \\
\text { artoys trocken Ten lande van ludick } \\
\text { [How Duke John and the Count of } \\
\text { Artois waged war in the land of Liège] }\end{array}$ & $\begin{array}{l}\text { John I of Brabant and Robert II of Artois } \\
\text { on horseback with their armies. Banners of } \\
\text { Artois and Brabant. }\end{array}$ & $42 r$ & 76 & $\begin{array}{l}1273- \\
1274\end{array}$ \\
\hline 50 & $\begin{array}{l}\text { Hoe de coninc van vrancrijc ridder } \\
\text { sloech hertoge janne ende Godeuaerde } \\
\text { sinen broeder } \\
\text { [How the King of France knighted } \\
\text { Duke John and his brother Godfrey] }\end{array}$ & $\begin{array}{l}\text { John I of Brabant and his younger brother } \\
\text { Godfrey kneel before King of France Philip } \\
\text { III who is backed by his knights. On the } \\
\text { verso page the walls of Paris. The coats of } \\
\text { arms are: Bourbon (France, differenced), } \\
\text { Brabant, Burgundy, France and Berry (?, } \\
\text { France, differenced). }{ }^{44}\end{array}$ & $\begin{array}{l}42 v- \\
43 r\end{array}$ & $\begin{array}{l}77- \\
78\end{array}$ & $\begin{array}{l}1272- \\
1276\end{array}$ \\
\hline
\end{tabular}

(44) The heraldry of the scene is not entirely in line with the period of time it depicts, as the marks of difference in French royal heraldry evolved over time. The leftmost coat of arms, 'azure, semé-de-lys or, a bend gules' - France with a red bend - was the coat of arms of Robert of Clermont (1256-1317), son of King Louis IX, considered founder of the house of Bourbon. The rightmost coat of arms is that of the Duchy of Berry, a fief often given to cadets of the French crown. The depicted coat of arms 'azure, semé-de-lys or, a bordure engrailed gules' - France with indented border in red - only occurs from 1360 onwards. The coat of arms of France plain, 'azure, three fleurs-de-lys or' - three gold fleurs-de-lis on a field of blue also represents a more recent state of French royal heraldry. 


\begin{tabular}{|c|c|c|c|c|c|}
\hline Ch. & Heading in ms. IV 684 & Image depiction & fol. & pp. & Year \\
\hline 51 & $\begin{array}{l}\text { Hoe hertoge jan in ingelant tornyerde } \\
\text { ende syne } n \text { zoen aens cony } n \text { cx dochter } \\
\text { bestaedde } \\
\text { [How Duke John entered a tourna- } \\
\text { ment in England and married his son } \\
\text { to the daughter of the King] }\end{array}$ & $\begin{array}{l}\text { Tournament. On the verso page a female } \\
\text { crowd on a grandstand, with the English } \\
\text { Queen as the central figure, spectating } \\
\text { a battle between a Brabantine party and } \\
\text { English party. Most of the combatants are } \\
\text { recognisable by the horsecloths on the recto } \\
\text { page, but a series of coats of arms on the } \\
\text { grandstand helps. }{ }^{45} \\
\text { The English side shows the royal coat of } \\
\text { arms, anachronistically followed by the coats } \\
\text { of Edward III of England and three his sons } \\
\text { (probably Edward the Black Prince, Lionel } \\
\text { of Antwerp and John of Gaunt), Alexan- } \\
\text { der III of Scotland, Albany, Warwick and } \\
\text { Bretagne. } \\
\text { For the Brabantine team: the Duke's son } \\
\text { John II of Brabant (see his differenced Bra- } \\
\text { bantine coat of arms), Gaasbeek, Wezemaal, } \\
\text { Rotselaar, Geten/Jauche, Diest, Breda and } \\
\text { Bierbeek. }\end{array}$ & $\begin{array}{l}43 \mathrm{v}- \\
44 \mathrm{r}\end{array}$ & $\begin{array}{l}79- \\
80\end{array}$ & 1279 \\
\hline 53 & $\begin{array}{l}\text { Hoe coninc philips te huwelijc nam } \\
\text { thertogen suster van brabant ende hoe } \\
\text { sij beclapt wart } \\
\text { [How King Philip took as his wife } \\
\text { the sister of the Duke of Brabant, and } \\
\text { how she was deceived] }\end{array}$ & $\begin{array}{l}\text { Philip III of France with his wife Mary of } \\
\text { Brabant who is carried off into a building by } \\
\text { two men. }\end{array}$ & $45 r$ & 82 & 1276 \\
\hline 54 & $\begin{array}{l}\text { Van her pyererts vander roetsen ver- } \\
\text { radernyssen } \\
\text { [Of Lord Pierre de la Broce's betrayal] }\end{array}$ & $\begin{array}{l}\text { John I of Brabant on horseback talks to his } \\
\text { imprisoned sister Mary, who stands behind a } \\
\text { barred window. }\end{array}$ & $46 r$ & 84 & 1277 \\
\hline 55 & $\begin{array}{l}\text { Hoe hertoge jan den coninc piertsen } \\
\text { hiesch te parijs } \\
\text { [How Duke John demanded Pierre } \\
\text { from the King in Paris] }\end{array}$ & $\begin{array}{l}\text { John I and Godfrey of Brabant, amongst } \\
\text { others, stand around King Philip III of } \\
\text { France. }\end{array}$ & $46 v$ & 85 & 1278 \\
\hline 56 & $\begin{array}{l}\text { Hoe die hertoge va } n \text { brabant piertsen } \\
\text { dede hangen te parijs an monfacon } \\
\text { [How the Duke of Brabant had Pierre } \\
\text { hanged in Paris at Montfaucon] }\end{array}$ & $\begin{array}{l}\text { Pierre de la Broce hanged at the Gibbet of } \\
\text { Montfaucon. Amongst the crowd are John I } \\
\text { and Godfrey of Brabant, on horseback. On } \\
\text { the recto page the city of Paris. }\end{array}$ & $\begin{array}{l}47 \mathrm{v}- \\
48 \mathrm{r}\end{array}$ & $\begin{array}{l}87- \\
88\end{array}$ & 1278 \\
\hline
\end{tabular}

(45) See also M. Damen "Heraldische plaagstoot?". We thank not only the author, but also the readers of his blog who reacted, providing some additions. It is difficult to ascertain with precision who the English, as well as the Brabantine contestants were. There is of course the distance between the illuminator and the depicted events, but also the fact that the tournament is not recounted in detail in the accompanying chronicle text. The Brabantine side seems to feature baenrotsen or banner lords that were as important in the late thirteenth century as they were in the middle of the fifteenth. The English side, however, presents the fourteenth-century heraldry of the court of Edward III rather than that of Edward I. This could either be a mistake - the illustrator may well have based his depiction on a fourteenth-century heraldic source - or could be a conscious message, as Damen suggests. Either way, we have chosen to include in the index only the kings (of England, as Edward I; and of Scotland, as Alexander III) and the Brabantine lords. The latter identifications too, however, have to remain hypothetical. 


\begin{tabular}{|c|c|c|c|c|c|}
\hline Ch. & Heading in ms. IV 684 & Image depiction & fol. & pp. & Year \\
\hline 57 & $\begin{array}{l}\text { Hoe de hertoge sijnre suster verloste } \\
\text { Ende cronen dede } \\
\text { [How the Duke freed his sister and } \\
\text { had her crowned] }\end{array}$ & $\begin{array}{l}\text { Mary of Brabant crowned Queen of France. } \\
\text { The King of France is amongst the crowd as } \\
\text { well as John I and Godfrey of Brabant. }\end{array}$ & $48 v$ & 89 & 1278 \\
\hline 58 & $\begin{array}{l}\text { Hoe deerste hertog jan int lant van } \\
\text { lymborch trac } \\
\text { [How Duke John I waged war in the } \\
\text { land of Limburg] }\end{array}$ & $\begin{array}{l}\text { John I of Brabant and his knights before a } \\
\text { city bearing the banner of Limburg. In the } \\
\text { background, a town in flames. }\end{array}$ & $49 r$ & 90 & 1283 \\
\hline 59 & $\begin{array}{l}\text { Hoe die hertoge te gulpen opden } \\
\text { berch sijn vyande } n \text { verbeyde met } \\
\text { machte } \\
\text { [How the Duke awaited his enemies } \\
\text { in force on the hill near Gulpen] }\end{array}$ & $\begin{array}{l}\text { The Brabantine and Limburg armies near } \\
\text { Gulpen (County of Jülich) A franciscan friar } \\
\text { kneels before John I of Brabant, pleading } \\
\text { peace. }\end{array}$ & $50 \mathrm{r}$ & 92 & $\begin{array}{l}1283- \\
1288\end{array}$ \\
\hline 60 & $\begin{array}{l}\text { Hoe hertoge ja } n \text { voer rode lach } \\
\text { [How Duke John lay before } \\
\text { Herzogenrath] }\end{array}$ & $\begin{array}{l}\text { An army carrying the Brabantine banner. In } \\
\text { the background, the town of 'Rode' (Herzo- } \\
\text { genrath) in flames. }\end{array}$ & $51 \mathrm{r}$ & 94 & $\begin{array}{l}1283- \\
1288\end{array}$ \\
\hline 61 & $\begin{array}{l}\text { Hoe die van trycht gescoffiert worde } n \\
\text { [How those of Maastricht were } \\
\text { defeated] }\end{array}$ & $\begin{array}{l}\text { Knights of Maastricht and Limburg in } \\
\text { combat under their banners, with the former } \\
\text { party on the losing side. }\end{array}$ & $51 \mathrm{v}$ & 95 & $\begin{array}{l}1283- \\
1288\end{array}$ \\
\hline 62 & $\begin{array}{l}\text { Hoe de here } n \text { voer tricht ware } n \\
\text { [How the Lords were before } \\
\text { Maastricht] }\end{array}$ & $\begin{array}{l}\text { Army on horseback in front of Maastricht. } \\
\text { Banners of Guelders, Cologne and Luxem- } \\
\text { bourg. The latter party is represented by } \\
\text { Count Henry VI. }\end{array}$ & $52 \mathrm{v}$ & 97 & $\begin{array}{l}1283- \\
1288\end{array}$ \\
\hline 64 & $\begin{array}{l}\text { Vande } n \text { strijde binnen ake } n \text { jegen des } \\
\text { hertoge } n \text { vriende } \\
\text { [Of the battle inside Aachen against } \\
\text { the friends of the Duke] }\end{array}$ & $\begin{array}{l}\text { Bloody battle inside the city of Aachen. } \\
\text { Flags of Aachen (imperial eagle), Brabant } \\
\text { (Boutersem), Berthout, Wezemaal and } \\
\text { Rotselaar. }{ }^{46}\end{array}$ & $53 \mathrm{v}$ & 99 & $\begin{array}{l}1283- \\
1288\end{array}$ \\
\hline 65 & $\begin{array}{l}\text { Hoe de bisscop van coellen voer aken } \\
\text { was } \\
\text { [How the Bishop of Cologne was } \\
\text { before Aachen] }\end{array}$ & $\begin{array}{l}\text { The Archbishop of Cologne, Siegfried II of } \\
\text { Westerburg, on horseback with his knights. } \\
\text { Canon fires at the Aachen walls. }\end{array}$ & $54 \mathrm{v}$ & 101 & $\begin{array}{l}1283- \\
1288\end{array}$ \\
\hline 69 & $\begin{array}{l}\text { Hoe de hertoge een poengijs vacht } \\
\text { voer spremont } \\
\text { [How the Duke battled before Spri- } \\
\text { mont] }\end{array}$ & $\begin{array}{l}\text { John I of Brabant on horseback with his } \\
\text { knights. In the back a burning windmill and } \\
\text { the city of Sprimont. }\end{array}$ & $56 \mathrm{r}$ & 104 & $\begin{array}{l}1283- \\
1288\end{array}$ \\
\hline 70 & $\begin{array}{l}\text { Hoe die hertoge de graue vanden } \\
\text { bare } n \text { te helpen reet } \\
\text { [How the Duke rode out tot he aid } \\
\text { of the Count of Bar] }\end{array}$ & $\begin{array}{l}\text { John I of Brabant on horseback shaking } \\
\text { hands with Theobald II, Count of Bar, who } \\
\text { is on foot. John's knights carry banners of } \\
\text { Brabant, Diest and Wezemaal. }\end{array}$ & $56 v$ & 105 & $\begin{array}{l}1283- \\
1288\end{array}$ \\
\hline
\end{tabular}

(46) The illustration depicts five knights in heraldic battle dress, adding the coat of arms of Yssche (IJse?) to the banners. This is in line with the accompanying text: Daer was die here van wesemael / Van ijsch mijn heer arnout / Ende ooc mede heer bertout / Heer lonijs van bautersem was daer / Ende mede heer jan van rotzelaer (comp. the edition of Velthem's continuation: Lodewijk van Velthems voortzetting van den Spiegel Historiael (1248-1316), ed. H. vander Linden, P. de Keyser \& A. van Loey (Brussels: Lamertin, 1906-1938), 3 vols Here: vol. 2, 415 (vv. 3491 ff.) It is difficult to identify with precision who is depicted and narrated as fighting in Aachen. We have included these knights in the index without added information, as they were mentioned in the text. 


\begin{tabular}{|c|c|c|c|c|c|}
\hline Ch. & Heading in ms. IV 684 & Image depiction & fol. & pp. & Year \\
\hline 73 & $\begin{array}{l}\text { Hoe die hertoge woeronck belach } \\
\text { [How the Duke lay siege to Wor- } \\
\text { ringen] }\end{array}$ & $\begin{array}{l}\text { Siege of Worringen. Banner showing the } \\
\text { combined coats of arms of Cologne and Jül- } \\
\text { ich. Knights rest in tents. John I of Brabant } \\
\text { is surrounded by knights. }\end{array}$ & $58 \mathrm{r}$ & 108 & 1288 \\
\hline 74 & $\begin{array}{l}\text { Hoe die hertoge ende sij } n \text { viande tot } \\
\text { malcanderen togen } \\
\text { [How the Duke and his enemies ap- } \\
\text { proached each other] }\end{array}$ & $\begin{array}{l}\text { John I of Brabant faces the Cologne Arch- } \\
\text { bishop Siegfried II of Westerburg, both with } \\
\text { an army of knights. Banners of Brabant, } \\
\text { Gaasbeek, Wezemaal and Diest on John's } \\
\text { side. On Siegfried's side those of Cologne, } \\
\text { Guelders and Limburg. }\end{array}$ & $59 \mathrm{r}$ & 110 & 1288 \\
\hline 75 & $\begin{array}{l}\text { DIt es den strijt van woeronck } \\
\text { [This is the Battle of Worringen] }\end{array}$ & $\begin{array}{l}\text { Battle of Worringen. Knights engaged in } \\
\text { combat. } \\
\text { On the left page, under the banners of Berg } \\
\text { and Brabant, knights dressed in heraldic } \\
\text { armour representing the city of Cologne, Bi- } \\
\text { erbeek, Rotselaar (facing downwards), Berg, } \\
\text { Wezemaal, Gaasbeek, Geten/Jauche, Breda, } \\
\text { a relative of Henry VI of Luxembourg (on } \\
\text { the ground), Limburg (on the ground) and } \\
\text { a relative of Henry VI of Luxembourg (on } \\
\text { the ground). } \\
\text { On the right page, under the banners of } \\
\text { Guelders, Luxembourg, Limburg and the } \\
\text { bishop of Cologne: knights dressed in the } \\
\text { heraldic armour of Brabant, Diest, the } \\
\text { bishop of Cologne (captured by knights), } \\
\text { Guelders (in the right margin), Henry VI of } \\
\text { Luxembourg (bending over) and one of his } \\
\text { relatives (on the ground). }{ }^{4}\end{array}$ & $\begin{array}{l}60 v- \\
61 \mathrm{r}\end{array}$ & $\begin{array}{l}113- \\
114\end{array}$ & 1288 \\
\hline 79 & $\begin{array}{l}\text { Wat ere } n \text { men den hertoge dede } \\
\text { [The honours the Duke received] }\end{array}$ & $\begin{array}{l}\text { Monks outside the Cologne city walls. One } \\
\text { of them holds a religious banner. On the } \\
\text { right side a boat with knights: Wezemaal, } \\
\text { Brabant, Diest, Jauche and Gaasbeek. Ban- } \\
\text { ners of Brabant and Limburg. }\end{array}$ & $63 v$ & 118 & 1288 \\
\hline
\end{tabular}

(47) The identifiable main combatants whose coats of arms are depicted have been included in the index. The illustration shows three scions of the Luxemburg house deceased, one alive. Three are known to have died: Count Henry VI, his brother Waleran I, and their half-brother Henry of Houffalize. Perhaps the fourth is a rendering of the young Count Henry VII, who would inherit the County at a young age and would become King and Emperor in Germany at a later stage. See A. Wauters, Le duc Jean Ier: le Brabant sous le règne de ce prince (1267-1294), Mémoires couronnés et autres mémoires XIII (Brussels: Académie Royale, 1862), $160-1$. 


\section{APPENDIX 2: INDEX OF PERSONS AND PLACES DEPICTED IN MS. IV 684}

\section{Index of Names}

Adelaide of Burgundy (c. 1233-1273), wife to Henry III of Brabant: 29r, 33r, 34r

Adeliza (Adelheid) (c. 1103-1151), daughter of Godfrey I and Queen of Engeland: 6r

Adolf V, Count of Berg (d. 1296): 60v-61r

Alexander III (1241-1286), King of Scotland: 43v-44r (?)

Anno II, Archbishop of Cologne (c. 1010-1075): 7r

Arnold II von Isenburg (c. 1190-1259), archbishop of Trier: 25r

Arnold III of Wezemaal (c. 1232-1291): 38r, 41r

Arnold IV of Wezemaal (d. 1302): 43v-44r (?), 60v-61r (?)

Arnold of Louvain (d. 1287), Lord of Breda: 43v-44r (?)

Arnold VI (d. 1296?), Lord of Diest: 43v-44r (?), 60v-61r (?), 63r (?)

Arnout van IJsch (Ysche, IJse?): 53v

Beatrice of Brabant (1225-1288), daughter of Henry II of Brabant and wife to Henry Raspe, Landgrave of Thuringia: $22 \mathrm{r}$

Berthout, heer: $53 \mathrm{v}$

Boutersem, lonijs (louijs?) van: $53 \mathrm{v}$

Clarissa, unmarried daughter of Godfrey I of Louvain/Brabant: 6r

Conrad III (1093-1152), King of Germany: 7v

Conrad IV (1228-1254), King of Germany and of Jerusalem: 30r

Edward I (1239-1307), King of England: 43v-44r (?)

Elisabeth of Brunswick (d. 1266), Countess of Holland: 25r

Ferdinand of Portugal (1188-1233), husband to Joan of Constantinople, and as such jure uxoris Count of Flanders: 16v

Floris V of Holland (1254-1296), Count of Holland: 31v

Frederick I Barbarossa (1122-1190), German Emperor: 30r

Frederick II (1194-1250), German Emperor: 30r (?)

Gerard (d. 1312), Lord of Rotselaar: 43v-44r (?), 53v, 60v-61r

Gerard II (III?), Lord of Jauche (Geten): 43v-44r (?)

Gerard IV of Jauche (d. 1293?): 60v-61r, 63r

Gerard of Wezemaal (d. 1308), Lord of Bergen-op-Zoom: 60v-61r, 63r

Godfrey I of Brabant the bearded (1095-1139), count of Louvain and Duke of Brabant: 5r,

Godfrey II of Brabant, Duke of Brabant (1107-1142): 6r, 8v

Godfrey II of Louvain (d. 1265), Lord of Perwez and Grimbergen: 37r

Godfrey III of Brabant, Duke of Brabant (c. 1140-1190): 9r, 10v, 11r, 12r

Godfrey of Brabant (1273/74-after 1283), son of John I of Brabant: 36v

Godfrey of Brabant (d. 1302), son of Henry III of Brabant: 33r, 43r, 46v, 47v, 48v, 60v-61r (as Lord of Bierbeek?)

Godfrey of Louvain-Gaasbeek, son of Godfrey of Louvain-Gaasbeek, Provost of Nivelles; or William Pipenpoy, Lord of Blaasveld, commander of the troops of Gaasbeek: 60v-61r, 63r

Godfrey of Louvain-Gaasbeek, son of Henry I of Brabant (1209-1253): 16v

Henry (?), Lord of Bierbeek: 43v-44r (?)

Henry I (1244-1308), Landgrave of Hesse: 35r

Henry I of Brabant, Duke of Brabant (1165-1235): 12v, 13v, 14v, 16v, 17v, 19v 
Henry I of Limburg (1059-1118), Duke of Limburg and Lower Lotharingia: 8r

Henry II of Brabant, Duke of Brabant (1207-1248): 16v, 20r, 23r, 23v, 24v, 26r, 27r, 28r

Henry III of Brabant (1231-1261), Duke of Brabant: 29r, 30r, 32v, 33r

Henry III of Guelders (d. 1285), bishop of Liège: 26r, 28r, 35r, 39r

Henry IV of Boutersem (1232-1294?): 37r

Henry IV of Brabant (1251-after 1272), Duke of Brabant: 30r, 33r, 34r, 40r

Henry of Brabant, son of Godfrey I and monk in Affligem: 6r

Henry of Houffalize, bastard of Luxemburg (d. 1288), half-brother to Henry VI, Count of Luxemburg: 60v$61 \mathrm{r}$

Henry of Louvain, Lord of Gaasbeek (c. 1245-1285): 37r, 43v-44r (?)

Henry Raspe (1204-1247), Landgrave of Thuringia and husband to Beatrice of Brabant: 22r

Henry VI (1165-1197), German Emperor: 30r

Henry VI (1252-1288), Count of Luxemburg: 52v, 60v-61r

Ida, daughter of Godfrey I of Louvain/Brabant and Countess of Cleves: 6r

Imagina of Loon (c. 1145-1214), second wife to Godfrey III of Brabant: 12r

John I of Brabant (1253-1294), Duke of Brabant: 30r, 33r, 34r, 36r, 36v, 40r, 41r, 42r, 43r, 46r, 46v, 47v, $48 \mathrm{v}, 49 \mathrm{r}, 50 \mathrm{r}, 56 \mathrm{r}, 56 \mathrm{v}, 58 \mathrm{r}, 59 \mathrm{r}, 60 \mathrm{v}-61 \mathrm{r}, 63 \mathrm{v}$

John II of Brabant (1275-131), Duke of Brabant: 36v, 43v-44r

Konrad von Hochstaden (d. 1261), archbishop of Cologne: 25r

Louis II (1229-1294), Duke of Bavaria, husband to Maria of Brabant: 21v

Lutgardis of Sulzbach (d. after 1162), wife to Godfrey II of Brabant: 7v, 10v (?),

Manuel I Komnenos (1118-1180, Byzantine Emperor: 30r

Margaret of Brabant (1276-1311), daughter of John I of Brabant, German Queen: 36v

Margaret of Brabant (d. 1277), daughter of Henry II of Brabant and abbess of Valduc: 22v

Margaret of Dampierre (c. 1251-1285), second wife to John I of Brabant: 36v

Margaret of France (1254/55-1271), wife to John I of Brabant: 36r

Margaret of Limburg (c. 1138-1172), wife to Godfrey III of Brabant: 11r

Maria of Brabant (1189/90-1260), daughter of Henry I and German Empress: 17v

Maria of Brabant (1226-1256) daughter of Henry II of Brabant: 21v

Maria of Brabant (1254-1322), daughter of Henry III of Brabant, Queen of France: 33r, 45r, 46r, 48v

Maria of Brabant (1278-1338), daughter of John I of Brabant, Countess of Savoy: 36v

Maria of Swabia (1201-1235), daughter of German King Philip, wife to Henry II of Brabant: 20r

Mary of France (c. 1198-1224), second wife to Henry I of Brabant: 13v, 17v (?),

Matilda of Boulogne (d. 1210), wife to Henry I of Brabant: $12 \mathrm{v}$

Matilda of Brabant (1224-1288), daughter of Henry II of Brabant and wife to Robert I of Artois: 21r

Otto II of Guelders (1215-1271), Count of Guelders: 35r

Otto IV, German Emperor: 17v

Philip III (1245-1285), King of France: 43r, 45r, 46v, 48v

Philip of Swabia (1177-1208), German King: 30r

Pierre de la Broce (c. 1230-1278), Chamberlain to Philip III of France: $47 \mathrm{v}-48 \mathrm{r}$

Raso I of Gavere, Lord of Breda (d. 1290): 60v-61r

Reginald I (1255-1326), Count of Guelders: 60v-61r

Renaud of Dammartin (c. 1165-1227), Count of Boulogne: 16v

Robert I of Artois (1216-1250) son of King Louis VIII of France, Count of Artois and husband to Matilda of Brabant: $21 \mathrm{r}$

Robert II of Artois (1250-1302), Count of Artois: 42r 
Rotselaar, heer jan van: $53 \mathrm{v}$

Siegfried II of Westerburg (d. 1297), Archbisshop of Cologne: 54v, 59r, 60v-61r

Sophie of Thuringia (1224-1275), wife to Henry II of Brabant: 23r

Theobald II (1221-1291), Count of Bar: 56v

Waleran I (d. 1288), Lord of Ligny, brother to Henry VI, Count of Luxemburg: 60v-61r

Wezemaal, die here van: $53 \mathrm{v}$

William I of Holland, Count of Holland: 16v

William II of Holland (1227-1256), Count of Holland and German King: 25r, 30r, 31v

William Longespée (c. 1176-1226), Count of Salisbury, halfbrother to John Lackland, King of England: 16v Wouter V Berthout (1238-1287), Lord of Mechelen: 37r

\section{Index of Places}

Sint-Truiden: $8 \mathrm{v}$

Grimbergen: 9v

Liège: $14 \mathrm{v}$

Brussels: 16v

Louvain: $19 \mathrm{v}, 27 \mathrm{r}, 38 \mathrm{r}$

Valduc: 22v

Cologne: 23v, 63v

Paris: $42 \mathrm{v}-43 \mathrm{r}, 47 \mathrm{v}-48 \mathrm{r}$ (Montfaucon)

Mechelen: 39r

Herzogenrath: 51r

Maastricht: $52 \mathrm{v}$

Aachen: 53v, 54v

Sprimont: 56r

Worringen: $58 \mathrm{r}$ 
